\title{
Evidence of soils and palaeosols in the Poznań Formation (Neogene, Polish Lowland)
}

\author{
Agata DUCZMAL-CZERNIKIEWICZ1, * \\ 1 Institute of Geology, Adam Mickiewicz University, Maków Polnych 16, 60-606 Poznań, Poland
}

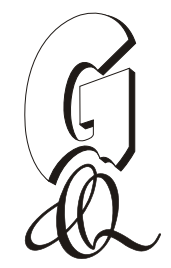

Duczmal-Czernikiewicz A. (2013) Evidence of soils and palaeosols in the Poznań Formation (Neogene, Polish Lowland). Geological Quarterly, 57 (2): 189-204, doi: 10.7306/gq.1082

\begin{abstract}
A succession of stacked palaeosol profiles was recognized in open pits in the western Wielkopolska region (Poland). Field observations and micromorphological studies made it possible to distinguish the following pedostructures, formed in contrasting environments: soil horizons, crystallaria, concretions, redoximorphic structures, Fe-Mn globulae and slickensides. In both soils (Holocene) and palaeosols (Pleistocene or/and Pliocene?), surface horizons are present (horizon A), marked by rhizocretions. There are two separate carbonate soils. One of them contains calcite concretions and gypsum pedofeatures, presumably formed in arid or semi-arid conditions. Two of the soil profiles are probably truncated, and only subsurface horizons are present (horizon B). In some cases, palaeosols are separated by sediment layers slightly influenced by pedogenesis (horizon BC). Carbonate soils (Bk) indicate water deficit during their formation. The presence of horizons with slickensides (Bss) indicates intervals with contrasting seasonal climates (wet and dry cycles). The profiles were influenced by gleying processes which caused redistribution of iron oxides and formation of iron and iron-manganese concretions. The pedostructures recognized reflect different climatic conditions as well as humidity changes during the time of their formation.
\end{abstract}

Key words: Poznań clays, Polish Lowland, pedostructures, palaeosols, Neogene.

\section{INTRODUCTION}

Palaeosols are common in ancient alluvial (Kraus, 1999), lacustrine and palustrine strata (Alonzo-Zarza, 2003), as well as in deltaic and coastal deposits (Wright, 1992). They are characterized by a set of typical structures that are diagnostic even if the soil processes are superimposed by diagenetic processes with surface weathering of the secondarily exposed soils.

The most important pedogenetic diagnostic structure is horizonation. The occurrence of other structures, characteristic of certain types of soils (Retallack, 1992, 1997), however, is also common: carbonate nodules (calcretes) and levels of carbonate concretions (calcic horizons), iron-manganese globules (globulae), rhizocretions, structures left by plant roots and mottling (red, rusty stains). The observed structures and mineral composition of clays of the Neogene Poznań Formation suggest that these deposits were formed under conditions typical of a soil environment (Piwocki et al., 2004). Subsequent processes, such as burial, secondary exposure due to glacitectonics and the effects of hypergenic processes, led to the imposition of modern soil-forming processes on the older fabrics of the deposit.

Recent years have seen intensification of research on palaeosols in terms of their structure, morphology, mineral and

\footnotetext{
* E-mail address: duczer@amu.edu.pl
}

Received: February 3, 2012; accepted: November 26, 2012; first published online: April 12, 2013 chemical composition (Alonzo-Zarza 2003; Alonzo-Zarza and Arenas, 2004; Hanneman and Wideman, 2006; Kraus and Hasiotis, 2006; Sheldon and Tabor, 2009; Alonzo-Zarza and Wright, 2010). This is due to the fact that palaeosols can provide vital information on the evolution of ancient climates and sedimentary environments. Much attention has been paid to the classification of palaeosols (Nettleton et al., 1999, 2000). As in the classification of contemporary soils, a variety of palaeosols is distinguished by a combination of typical features, dependent both on the parent material and the weathering factors that have led to their formation. Both the typical structures and chemical and mineral composition of the soil enable classification into a particular genetic category. Some structures characteristic of the development of palaeosols are commonly observed in the Poznań clays, although the contemporary pedogenic processes have blurred the original fabrics.

The aim of this paper is to characterise pedofeatures recognized in clayey deposits of the Poznań Formation on the basis of their sedimentology, mineralogy and petrology. Special attention was given to those pedological features which indicate evidence of vegetation development and palaeohydrology (water availability). Another aim was to differentiate those structures and textures which are the result of modern and older (Pliocene?) pedogenetic processes. These structures indicate distinct features developed in different climatic and environmental conditions. Micromorphological and field studies made it possible to recognise intervals with contrasting environments and seasonal cycles. In the deposits studied different horizons were observed, from those slightly influenced by pedogenesis (BC), to strongly developed soil structures, e.g., rhizoconcretions (Bk and Bssk horizons). 


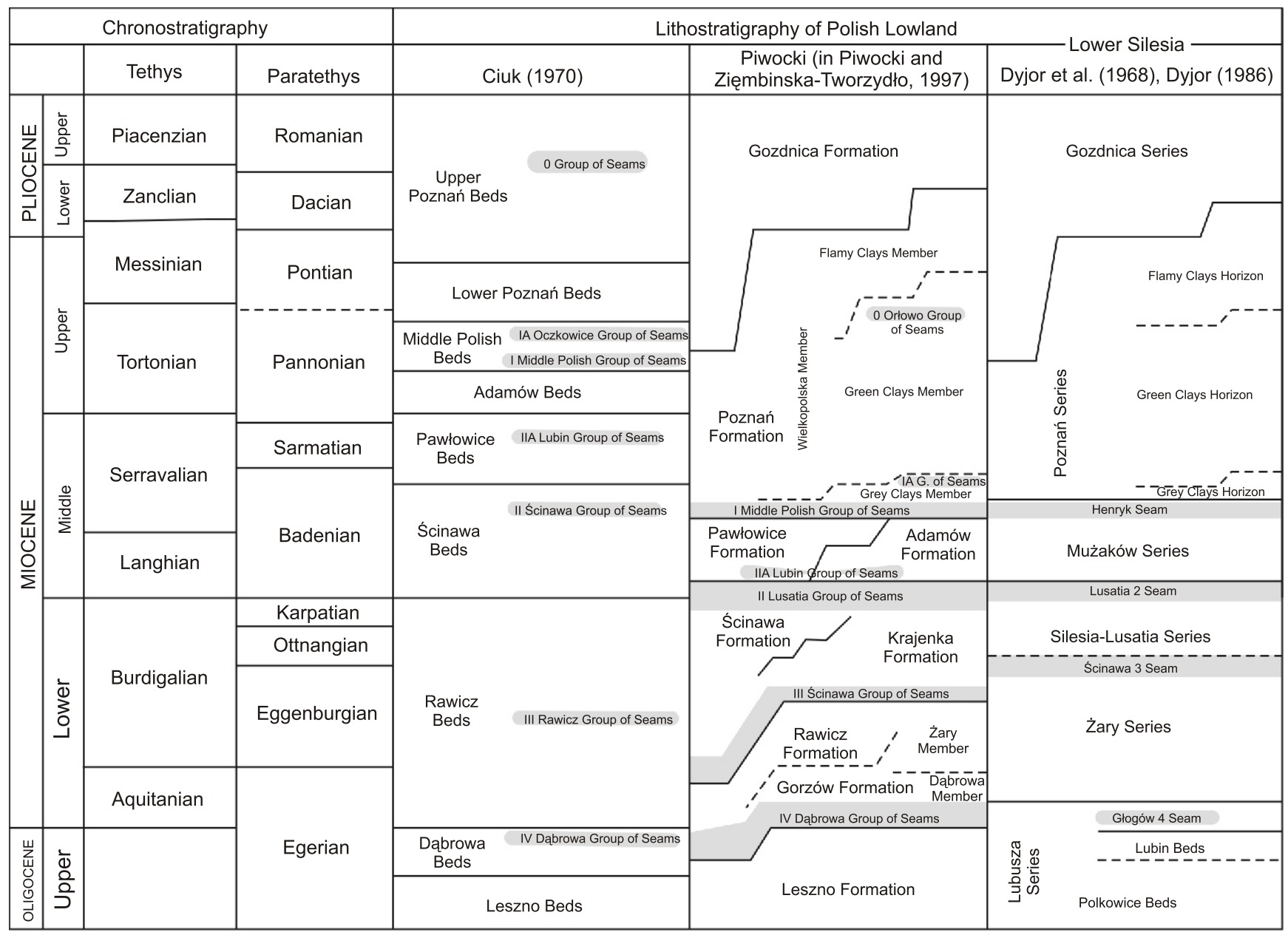

Fig. 1. Lithostratigraphy and chronostratigraphy of the Polish Lowland (according to Ciuk, 1970; Dyjor, 1986; Piwocki and Ziembińska-Tworzydło, 1997; Gedl and Worobiec, 2005)

The top layer of the area studied: the Gozdnica Formation, occurs to the south of the research area; in the central part of the Polish Lowland the Poznań clays occur, overlain by glacigenic deposits; in many parts of Europe the Neogene deposits have undergone erosion, as was frequently suggested (e.g., Piwocki et al., 2004; Kovács et al., 2008; Rasser and Harzhauser, 2008)

Neogene palaeosols from southern Europe (e.g., Alonzo-Zarza and Arenas, 2004), northern America (e.g., Retallack, 2004), Africa (e.g., Bamford et al., 2008) and Asia (e.g., Kovda et al., 2008) are very well-documented. In central Europe, however, palaeosol profiles are poorly recognised. Moreover, climatic conditions around the Miocene-Pliocene boundary in Eurasia are still insufficiently known (Utescher et al., 2011) and strongly dependent on local factors. Although the stratigraphy of the palaeosols studied in this paper is not clear (Fig. 1), the analysis has revealed episodes of environmental change (e.g., dry or wet cycles) during the formation of the soil succession.

The Poznań clays have been the subject of scientific research since the beginning of the 20th century. A particular interest was shown in the years of a prospering ceramic materials industry (1960-1990; Szyszło, 1967; Dyjor et al., 1968; Ciuk, 1970; Dyjor, 1970; Walkiewicz, 1984). The most complete mineralogical characteristics of this succession was described by Wiewióra and Wyrwicki (1974, 1976), Wyrwicki (1975) and Wichrowski (1981).

Previous studies of the Poznań sediment formation were based on field studies and laboratory tests of the chemical and mineral composition (Wichrowski, 1981, with references therein) except for a few studies (Wyrwicki and Maliszewska,
1977; Duczmal-Czernikiewicz, 2011), where microscopic observations were used.

Weathering indices, based on major and trace elements, were calculated by Duczmal-Czernikiewicz (2010). A specialist literature compilation and the summary of the long discussions on the genesis were conducted by Piwocki et al. (2004), who attributed the development of the top sections of the Poznan Formation, which includes the Poznań clays, to soil-forming processes.

\section{METHODS AND TERMINOLOGY}

The Poznań clays were studied in three pits in the Wielkopolska region located south of Poznań (Fig. 2) in Witaszyce, Brzostów and Dymaczewo Stare. The exposure at Dymaczewo is now accessible at its top only, because extraction has ceased, the deposit in Witaszyce is extracted seasonally, while the Poznań clays at Brzostów are exploited for the building ceramics industry. The deposits were sampled in two exposures along vertical profiles, as long as local conditions allowed that. Sixty collected samples were subjected to microscopic and macroscopic observations. They were also analysed with the use of the following methods: X-ray diffraction, 


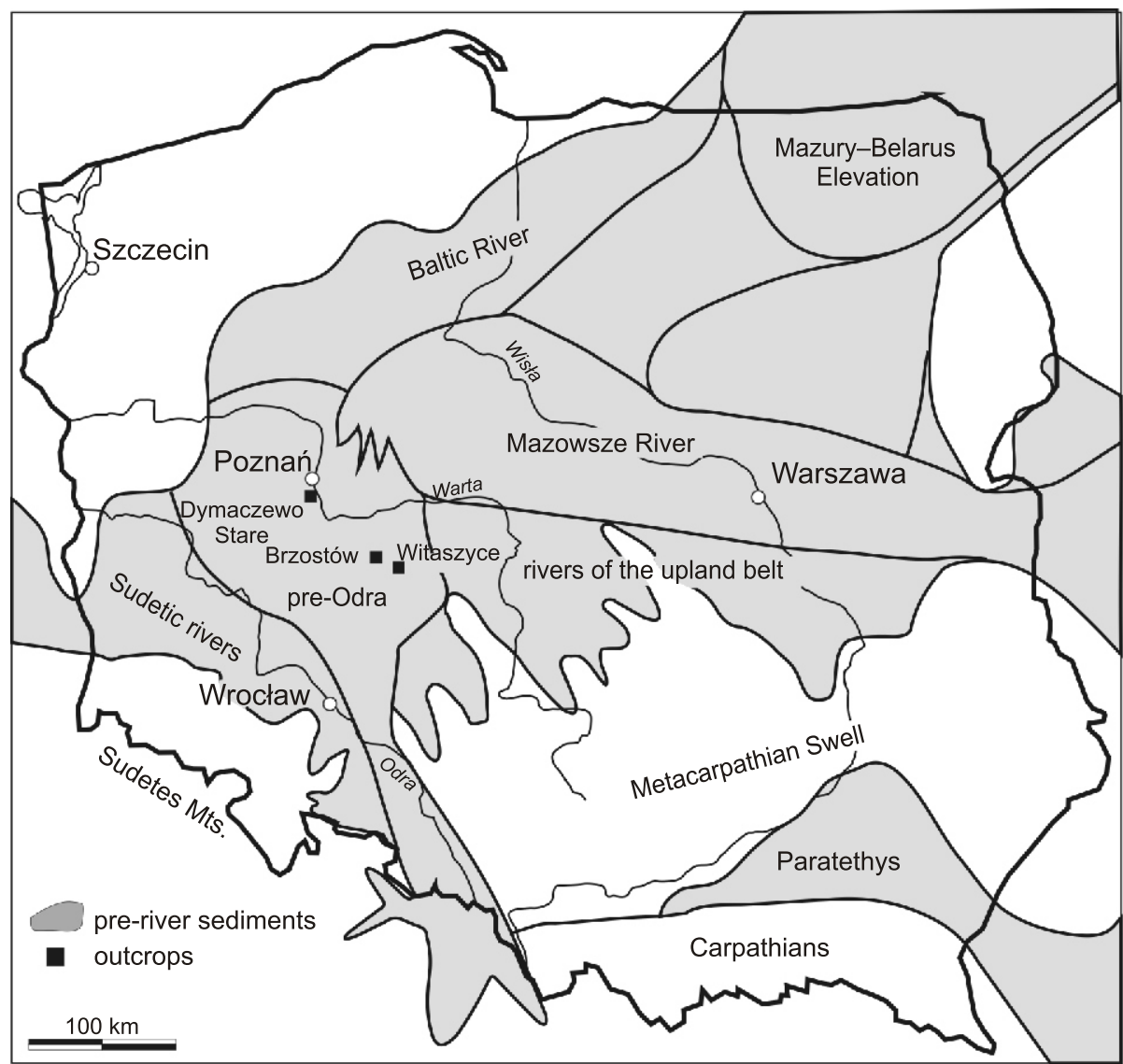

Fig. 2. Location map of the exposures, which are situated in areas of post-Miocene fluvial accumulation (according to Piwocki et al., 2004)

The area studied is located in the pre-Odra River Basin

XRF and ICP-MS. Different fractions of grain components were also examined using $X$-rays, while the proportion of quartz was determined in thin sections. The colour of the deposits was recorded using a Munsell scale. The X-ray method determined the mineral composition of the bulk samples and the clay fraction. The XRF and ICP-MS methods were used to determine the chemical composition of the bulk samples. The methodology was based on the work by Retallack (1988, 1991, 1997).

The solum is the most altered upper part of a soil profile (not much thicker than $2 \mathrm{~m}$ ) and is the material that most accurately reflects vegetation and other soil-forming environmental factors (Retallack, 1997). Various kinds of soil horizons are named on the basis of the solum.

The term diagnostic horizon is used for each of the distinctive layers that occur in a soil, containing a combination of characteristics typical of that kind of soil. Each soil type has at least one, but usually three or four, different horizons. From the top to bottom these are $\mathrm{A}, \mathrm{B}$, and $\mathrm{C}$ horizons. Moreover, there could be an $\mathrm{O}$ layer at the top, above $\mathrm{A}$, and an $\mathrm{E}$ layer below the $\mathrm{A}$ horizon (Fig. 3 and Table 1).

The diagnostic features of the main horizon are designated by using the lower case symbols (Table 1). Some of the features are more diagnostic then others (e.g., illuvial accumulation of clays, development of colour or structure), so their descriptors should be written first ("t" or "w", respectively). Development of soil features in different regimes enables their classification via description of the horizons.

Palaeosol development, designated as maturation, is based on solum thickness, horizon development, ped structure

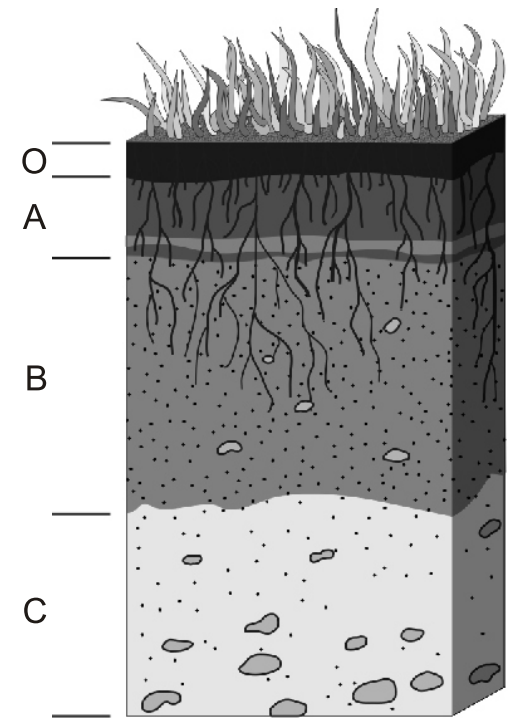

Fig. 3. Formal soil profile (according to www.eoearth.org/article/Soil) with designation of soil horizons

O - humus horizon, A - topsoil, dark horizon enriched with organic matter, B subsoil, accumulation level, C - parent rocks, slightly influenced by pedogenesis; further explanation in the text and in Table 1 
Table 1

Formal soil horizon (according to Soil Survey Staff, 1990)

\begin{tabular}{|l|r|}
\hline \multicolumn{2}{|c|}{ Base symbols for surface horizons } \\
\hline O & $\begin{array}{r}\text { organic horizon containing litter } \\
\text { and decomposed organic matter }\end{array}$ \\
\hline A & $\begin{array}{r}\text { mineral horizon darkened by humus accumulation } \\
\text { mineral horizon lighter in colour than the A or O horizon } \\
\text { and depleted in clay minerals }\end{array}$ \\
\hline B & accumulated clay and humus below the A or E horizon \\
\hline C & material below the A or B horizon \\
\hline C & Suffixes added for special features of horizons \\
\hline g & concretions or hard nodules \\
\hline k & gray colour with strong mottling and poor drainage \\
\hline $\mathrm{m}$ & accumulation of carbonate \\
\hline $\mathrm{n}$ & cementation or induration \\
\hline $\mathrm{O}$ & accumulation of sodium \\
\hline $\mathrm{S}$ & accumulation of oxides of iron and aluminum \\
\hline $\mathrm{Ss}$ & slickensides \\
\hline $\mathrm{t}$ & stacked slickensides \\
\hline $\mathrm{w}$ & accumulation of clay \\
\hline $\mathrm{X}$ & fragipan character (high-density, brittle) \\
\hline $\mathrm{y}$ &
\end{tabular}

and pedogenic carbonate content (Retallack, 1988). Palaeosols, thus, can be very immature (stage 0), poorly developed (stage 1), moderately developed (stage 3 ) and the most mature (stage 4).

Soil morphology distinguishes aggregate and non-aggregate structures (Retallack, 1997). Similarly, palaeosols are built of mineral aggregates (peds), which in terms of size may be differentiated into the following categories: granular or crumb (a few millimetres in size), angular blocky (centimetres in size), and massive (tens of centimetres in size). Globules in soils are formed by segregation of material which differs in colour and mineral composition from other parts of the soil. The mineral composition of globules depends on the chemical and physical conditions on the soil surface during the forming processes. They can take various forms of different macro- and microstructures: nodules, concretions and septaria. Nodules show concentric fabric, concretions show massive fabric, while septarian nodules or concretions have internal cracks due to shrinkage or hydraulic fracturing. These cracks may be filled by carbonates (calcite) or/and sulphates (gypsum).

\section{RESULTS}

\section{CLAY LEVELS}

Among the clays studied there were "levels" of green and red clays which occur alternately (Figs. 4 and 5). The red and green intercalations are in a different position in each of the open pits investigated, and they do not indicate horizontal continuity.

The grain-size variability is independent of the colour of the deposit, and in both greenish and red varieties the content of the sandy fraction increases to $50 \%$ in places, creating lenses and sandy horizontal beds. Silica content varies from 57 to 90.82 wt.\%, and aluminium from 3.8 to 19.96 wt.\% (Table 2). Levels of green clay with a bluish hue is formed of sediments of a massive structure, relatively homogeneous, devoid of aggregates, with poorly visible cracks and without root traces (Fig. 4A). Some of the blue-green sediments are coarser than the mottled varieties as they are dominated by silt. They include carbonates in the form of calcite (calcretes) and marl concretions, and in places in the form of intercalations and lenses. Rusty coloured clays are either present on the surface, or they form horizons coloured with iron oxides in the form of intercalations in the green clays under the surface of the terrain (Figs. 4B and $5 A$ ). In the wet state they show a strong plasticity, while in the dried state they are compact. The dry clay is highly fractured and is found in the form of hard irregular lumps or separate sharp-edged fragments. In the upper, near-surface parts of the profiles, numerous traces of plant roots (modern) are observed. Locally in the lower parts of root traces there are iron oxides and iron sulphates (Fig. 5B). In the lower parts of the profiles the sediments are fractured into blocks (a few millimetres to several centimetres long).

Variegated colouration occurs in the form of irregular clusters or thin films, composed of iron oxides and hydroxides. Microscopic observations in transmitted and reflected light indicates the occurrence of variously shaped spots: spherical, spherulitic, fan-like and irregular, arranged according to clay distortions. Discolouration (bleaching) has either a sharp or gradational contact with the sediment. In many places there are clusters of concentrations of brown or black iron-manganese oxides (Fig. 5C) up to several millimetres across. The X-ray studies made it possible to distinguish two major mineral phases from which the colour originated in the patches in the variegated clays: cherry-red hematite and rusty and yellowish-brown goethite, which also forms brown and rusty concretions and globules in the deposits. Goethite is present both on the contemporary surface and in the lower parts of the soil profiles, whereas red hematite usually occurs beneath the surface, up to a few metres deep, in the form of the following colour succession (from top to bottom): green - pale red-cherry-red (Figs. 6 and 7). In places, goethite and hematite occur together (Fig.8), indicating changes in chemical conditions.

\section{AGGREGATES (PEDS)}

In the profiles examined the following categories of peds were observed:

- grainy or nut-like, small, a few millimetres in size (granular or crumb), which are observed on the surface of the exposures, as well as beneath the surface;

- prisms of up to several centimetres in which aggregates have flat surfaces and sharp edges; most often they overlie younger deposits (angular blocky);

- massive, with a predominance of clay or dust fraction, forming large irregular lumps of compact structure and up to tens of centimetre across.

In the exposures examined different structures were observed, from coarse to very fine aggregate (Figs. 4-7). The clay surface contains fine crumbs which, towards the bottom, become coarser and coarser and increasingly massive. The change in the size of aggregates from coarse $(10 \mathrm{~cm})$ or blocks at the base of the exposures (lower horizons) to very small $(0.5 \mathrm{~cm})$ upwards, suggests the formation of these structures took place simultaneously with soil forming processes. 

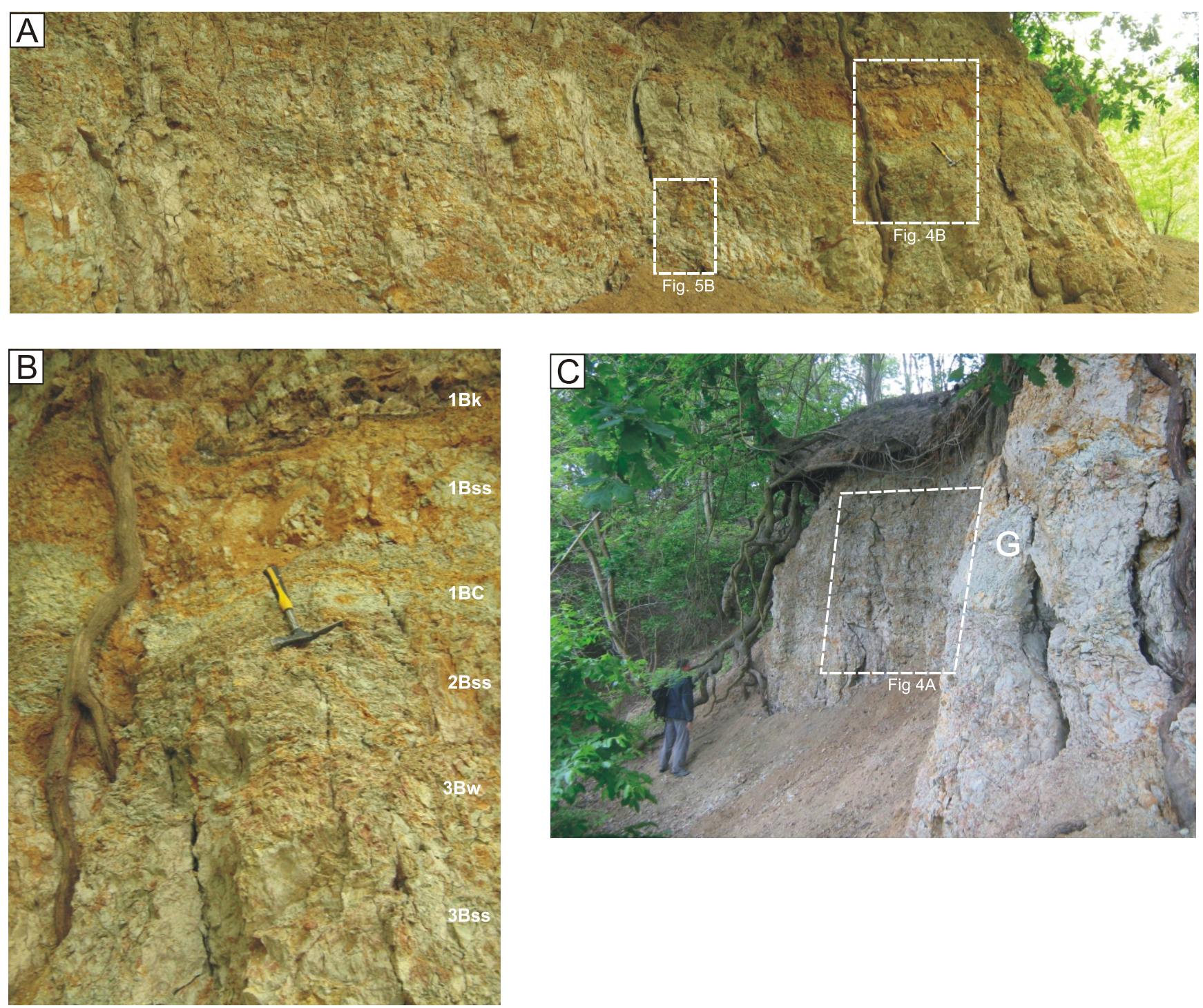

Fig. 4. The contemporary and an older pedostructures identified in Dymaczewo profile

A - general view on the Dymaczewo Stare exposures; some fragments enlarged in a separate photo (frame); the profile of a contemporary (Holocene) soil developed on the older soil profiles (see also Fig. 4C); the changes of colourations and structures indicate changes in water and oxygen availability which might be correlated with soil development and horizons; the hammer handle is $35 \mathrm{~cm}$ long; B - stacked soil profil from the top: Holocene soils (designated as 1) with 1Bk, 1Bss, 1BC horizons of the first soil profile; older (designated as 2 and 3 ) (probably Pleistocene) palaeosol profiles (enlargment of Fig. 4A); C - gleying horizon of palaeosol at a depth of $5 \mathrm{~m}$ below the modern surface; the red (iron oxides) and black (manganese oxides) mottles in grey-green matrix indicate iron and manganese migration in a humid and oxygenated environment; G - gilgai microrelief (pedostructures formed during wet-dry cycles); these structures occur mostly in Vertisol-like soils; gilgai microrelief, and sharp contact with older soils with platy-crumb structure below, may be remnants of the subsoil horizon of an older soil; grey-green clays are prismatic or massive (slightly influenced by pedogenesis), while the rusty and red generally fine and grainy (moderate to strong development of pedogenesis)

\section{SLICKENSIDES}

Slickensides are polished, smooth surfaces which are formed along the shearing surface, creating a zone where aggregates move in relation to each other in either micro- or mesoscale (visible in the exposure scale) of $10-15 \mathrm{~cm}$ to a millimetre or less (Figs. 9-12) in size. They are visible in massive (usually green), prismatic (block) clay types as well as in fine-grain types (yellowish-rusty and brown) in the form of crushed fragments.

The microscopic observations also reveal characteristic shearing zones, indicating the movement of sediment fragments in relation to each other. Torn - oval or concentric-sedi- ment components are often visible, which demonstrates that movement of some blocks in relation to each other took place after they had formed.

\section{GLOBULES}

In the sediments examined there were numerous manganese and iron globules (Fig. 13), mostly spherical, from fine of less than $5 \mathrm{~mm}$ across to coarse of over $15 \mathrm{~mm}$ across, as well as nodules composed of iron oxides up to a few centimetres. The iron oxides seem to be pseudomorphs after cubic pyrite (Fig. 14). In the green clays (Brzostów) there are manganese globules of small and medium size. In all exposures examined 

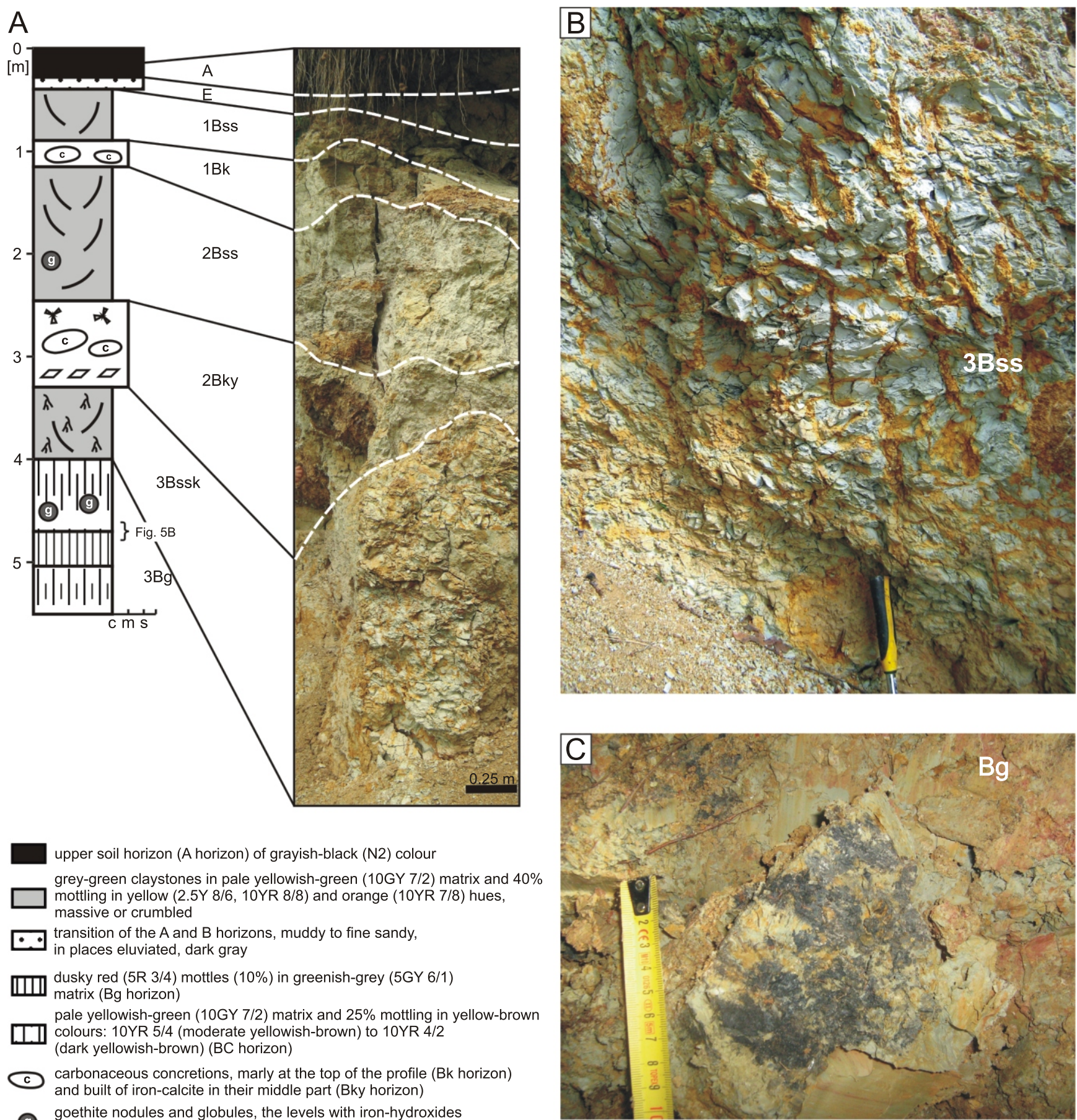

upper soil horizon (A horizon) of grayish-black (N2) colour

grey-green claystones in pale yellowish-green (10GY 7/2) matrix and 40\% mottling in yellow (2.5Y 8/6, 10YR 8/8) and orange (10YR 7/8) hues, massive or crumbled

transition of the A and B horizons, muddy to fine sandy, in places eluviated, dark gray

IIII dusky red (5R 3/4) mottles (10\%) in greenish-grey (5GY 6/1) matrix (Bg horizon)

pale yellowish-green (10GY $7 / 2$ ) matrix and $25 \%$ mottling in yellow-brown colours: 10YR 5/4 (moderate yellowish-brown) to 10YR 4/2 (dark yellowish-brown) (BC horizon)

(c) carbonaceous concretions, marly at the top of the profile (Bk horizon) and built of iron-calcite in their middle part (Bky horizon)

goethite nodules and globules, the levels with iron-hydroxides concentrations are assigned to horizons Bss, Bssk, Bky and Bg

gypsum rosettes in gray and yellowish-gray clays (in Bky horizon) gypsum single crystals (up to $5 \mathrm{~cm}$ long), also some ridged carbonate $\boldsymbol{\sigma}$ concretions (Bk)

yellow (2.5Y 8/6) and vivid brown (7.5YR 7/8) rhizocretion consisting of iron

$\lambda$ sulphate (jarosite) on the root remnants, forming elongated mottles $(20 \%)$ with slickensides, correspond with the 3Bss horizon (Fig. 5B)

slickensides observed in meso- and microscale (correspond to Bss horizon)

Fig. 5. Stacked plaeosols profile and different soil horizons

A - simplified lithological profile of the stacked palaeosol profile in an old open pit (Dymaczewo Stare); the colours of the deposits are generally yellowish-brown and are masked by pedogenic features; c - clays, $\mathrm{m}$ - muds, $\mathrm{s}$ - silts fraction; B - root traces preserved as iron oxides (goethite) and iron sulphates (jarosite) in gray-green matrix, indicating the development of soils above the water table; redox concentration patches in gray-green matrix indicates that roots are reduced under oxygenated conditions; the horizon with rhizocretions is up to $1.2 \mathrm{~m}$, in places; the hammer handle is $35 \mathrm{~cm}$ long; $\mathbf{C}$ - older soil horizon - root traces (thin, red) in gray matrix: gleyed horizon (Bg) of a palaeosol found at a depth of 5 metres below the modern soil surface; the red (iron oxides) and black (manganese oxides) mottles concentrated below level of iron oxides enrichment; mottles in grey-green matrix indicate iron and manganese migration in a humid environment, where iron could be bacterially reduced 
Chemical composition of selected samples

\begin{tabular}{|c|c|c|c|c|c|c|c|c|c|c|c|c|c|c|c|c|c|c|c|c|c|c|}
\hline No. & $\begin{array}{l}\text { Sam- } \\
\text { ple }\end{array}$ & Method & $\mathrm{SiO}_{2}$ & $\mathrm{Al}_{2} \mathrm{O}_{3}$ & $\mathrm{Fe}_{2} \mathrm{O}_{3}$ & $\mathrm{MnO}$ & $\mathrm{MgO}$ & $\mathrm{CaO}$ & $\mathrm{Na}_{2} \mathrm{O}$ & $\mathrm{K}_{2} \mathrm{O}$ & $\mathrm{TiO}_{2}$ & $\mathrm{P}_{2} \mathrm{O}_{5}$ & V & $\mathrm{Cr}$ & $\mathrm{Rb}$ & $\mathrm{Sr}$ & Y & $\mathrm{Zr}$ & $\mathrm{Nb}$ & $\mathrm{Ba}$ & LOI & Sum \\
\hline 1 & WI2 & ICP-MS & 58.97 & 17.07 & 8.47 & 0.099 & 1.24 & 0.59 & 0.11 & 2.09 & 0.8 & 0.11 & 130 & 119 & 130 & 64 & 23 & 171 & 15 & 333 & 10.1 & 99.64 \\
\hline 2 & WI2 & ICP-MS & 60.06 & 17.42 & 5.94 & 0.079 & 1.23 & 0.59 & 0.11 & 2.16 & 0.853 & 0.07 & 119 & 122 & 131 & 67 & 20 & 180 & 16 & 338 & 10.23 & 98.75 \\
\hline 3 & WI3 & ICP-MS & 57.95 & 18.61 & 5.26 & 0.075 & 1.16 & 0.88 & 0.1 & 1.68 & 0.907 & 0.05 & 140 & 126 & 161 & 80 & 16 & 141 & 18 & 310 & 12.97 & 99.64 \\
\hline 4 & W III 1 & ICP-MS & 54.33 & 19.96 & 7.11 & 0.026 & 1.59 & 0.78 & 0.1 & 2.46 & 0.791 & 0.09 & 169 & 132 & 181 & 88 & 23 & 104 & 16 & 4040 & 12.32 & 99.56 \\
\hline 5 & W III 2 & ICP-MS & 53.87 & 19.35 & 9.63 & 0.042 & 1.7 & 0.67 & 0.12 & 2.81 & 0.828 & 0.13 & 162 & 155 & 165 & 77 & 21 & 100 & 16 & 369 & 10.89 & 100.04 \\
\hline 6 & W III 3 & ICP-MS & 57.08 & 18.15 & 7.21 & 0.039 & 1.32 & 0.68 & 0.11 & 2.28 & 0.936 & 0.09 & 165 & 113 & 181 & 86 & 23 & 128 & 19 & 384 & 11.23 & 99.12 \\
\hline 7 & W III 4 & ICP-MS & 53.71 & 19.53 & 9.19 & 0.041 & 1.63 & 0.7 & 0.12 & 2.57 & 0.817 & 0.12 & 170 & 131 & 175 & 82 & 22 & 106 & 16 & 362 & 11.64 & 100.07 \\
\hline 8 & W IV 1 & ICP-MS & 64.84 & 16.03 & 4.09 & 0.016 & 1.49 & 0.6 & 0.35 & 2.8 & 0.869 & 0.05 & 123 & 109 & 153 & 70 & 32 & 166 & 16 & 408 & 7.82 & 98.97 \\
\hline 9 & W IV 2 & ICP-MS & 68.66 & 12.8 & 5.9 & 0.07 & 0.83 & 0.63 & 0.4 & 2.25 & 0.841 & 0.09 & 96 & 121 & 116 & 60 & 21 & 300 & 16 & 377 & 7.4 & 99.87 \\
\hline 10 & W VI 1 & ICP-MS & 59.17 & 18.15 & 5.88 & 0.012 & 1.14 & 1.03 & 0.08 & 1.6 & 0.751 & 0.09 & 141 & 132 & 147 & 63 & 19 & 178 & 14 & 289 & 11.66 & 99.57 \\
\hline 11 & W VI 2 & ICP-MS & 54.32 & 19.11 & 9.4 & 0.015 & 1.26 & 1.14 & 0.08 & 1.76 & 0.714 & 0.14 & 170 & 167 & 178 & 70 & 16 & 127 & 14 & 273 & 12.1 & 100.03 \\
\hline 12 & D2 & XRF & 28.12 & 9.89 & 5.43 & 0.05 & 0.55 & 15.07 & 0 & 0.76 & 0.31 & 0.04 & 54 & 55 & 64 & 112 & 33 & 63 & 0 & 844 & 15.85 & 83.47 \\
\hline 13 & D5 & XRF & 58.35 & 18.73 & 3.78 & 0.01 & 1.43 & 2.64 & 0.13 & 2.97 & 0.93 & 0.04 & 128 & 110 & 162 & 111 & 34 & 123 & 12 & 456 & 8.765 & 98.91 \\
\hline 14 & D9 & XRF & 26.16 & 5.08 & 53.27 & 2.41 & 0.49 & 0.44 & 0.17 & 0.87 & 0.31 & 0.17 & 62 & 57 & 49 & 92 & 387 & 103 & 12 & 349 & 10.99 & 100.7 \\
\hline 15 & B1_1 & XRF & 87.84 & 6.04 & 1.47 & 0.01 & 0.32 & 0.2 & 0.3 & 1.27 & 0.25 & 0.02 & 0 & 21 & 57 & 44 & 0 & 109 & 10 & 288 & 2.096 & 99.88 \\
\hline 16 & B1_2 & XRF & 73.82 & 10.1 & 5.92 & 0.36 & 0.74 & 0.53 & 0.27 & 1.74 & 0.59 & 0.05 & 77 & 68 & 90 & 60 & 23 & 250 & 12 & 344 & 5.414 & 99.66 \\
\hline 17 & B1_3 & XRF & 76.83 & 11.04 & 2.98 & 0.02 & 0.76 & 0.45 & 0.4 & 1.89 & 0.66 & 0.03 & 84 & 75 & 93 & 66 & 23 & 247 & 16 & 441 & 3.806 & 99.01 \\
\hline 18 & B1_4 & XRF & 89.03 & 5.04 & 1.31 & 0.01 & 0.27 & 0.16 & 0.47 & 1.29 & 0.31 & 0.02 & 0 & 18 & 48 & 46 & 0 & 251 & 12 & 314 & 1.285 & 99.26 \\
\hline 19 & B1_5 & XRF & 90.82 & 3.8 & 0.86 & 0 & 0.18 & 0.1 & 0.46 & 1.19 & 0.2 & 0 & 0 & 13 & 46 & 41 & 9 & 134 & 0 & 247 & 0.8742 & 98.55 \\
\hline 20 & B1_6 & XRF & 79.38 & 8.99 & 3.07 & 0.05 & 0.57 & 0.39 & 0.53 & 1.73 & 0.52 & 0.03 & 57 & 53 & 78 & 64 & 17 & 215 & 13 & 422 & 4.059 & 99.42 \\
\hline 21 & B1_7 & XRF & 86.81 & 6.22 & 1.63 & 0.01 & 0.4 & 0.2 & 0.53 & 1.49 & 0.39 & 0.02 & 0 & 26 & 64 & 48 & 11 & 233 & 0 & 300 & 1.741 & 99.52 \\
\hline 22 & B2_10 & XRF & 74.22 & 11.3 & 3.22 & 0.01 & 0.97 & 0.34 & 0.44 & 2.12 & 0.67 & 0.03 & 105 & 82 & 103 & 67 & 26 & 244 & 15 & 345 & 5.249 & 98.69 \\
\hline 23 & B2_13 & XRF & 65.5 & 16.07 & 5.69 & 0.02 & 1.48 & 0.62 & 0.27 & 2.45 & 0.82 & 0.08 & 132 & 105 & 134 & 80 & 33 & 197 & 10 & 374 & 6.611 & 99.74 \\
\hline 24 & B2_14 & XRF & 73.17 & 9.68 & 3.47 & 0.15 & 0.86 & 2.49 & 0.62 & 1.98 & 0.59 & 0.3 & 71 & 68 & 94 & 83 & 33 & 299 & 20 & 598 & 5.792 & 99.27 \\
\hline 25 & B2_15 & XRF & 56.73 & 18.83 & 7.97 & 0.07 & 1.75 & 1.19 & 0.13 & 2.86 & 0.81 & 0.13 & 138 & 116 & 168 & 89 & 41 & 119 & 12 & 368 & 8.765 & 99.38 \\
\hline 26 & B2_16 & XRF & 71.85 & 13.32 & 4.44 & 0.07 & 1.18 & 0.46 & 0.35 & 2.32 & 0.76 & 0.04 & 95 & 79 & 122 & 74 & 32 & 238 & 14 & 632 & 5.053 & 99.98 \\
\hline
\end{tabular}

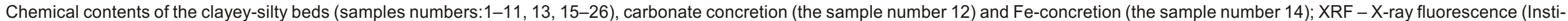

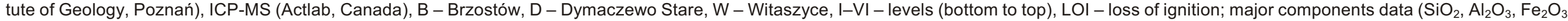
$\mathrm{MnO}, \mathrm{CaO}, \mathrm{Na}_{2} \mathrm{O}, \mathrm{K}_{2} \mathrm{O}, \mathrm{TiO}_{2}, \mathrm{P}_{2} \mathrm{O}_{5}$ ), and $\mathrm{LOI}$ measured in weight percent [weight \%], traces: $\mathrm{V}, \mathrm{Cr}, \mathrm{Rb}, \mathrm{Sr}, \mathrm{Y}, \mathrm{Zr}$, Nb, and Ba measured in parts per million [ppm] 


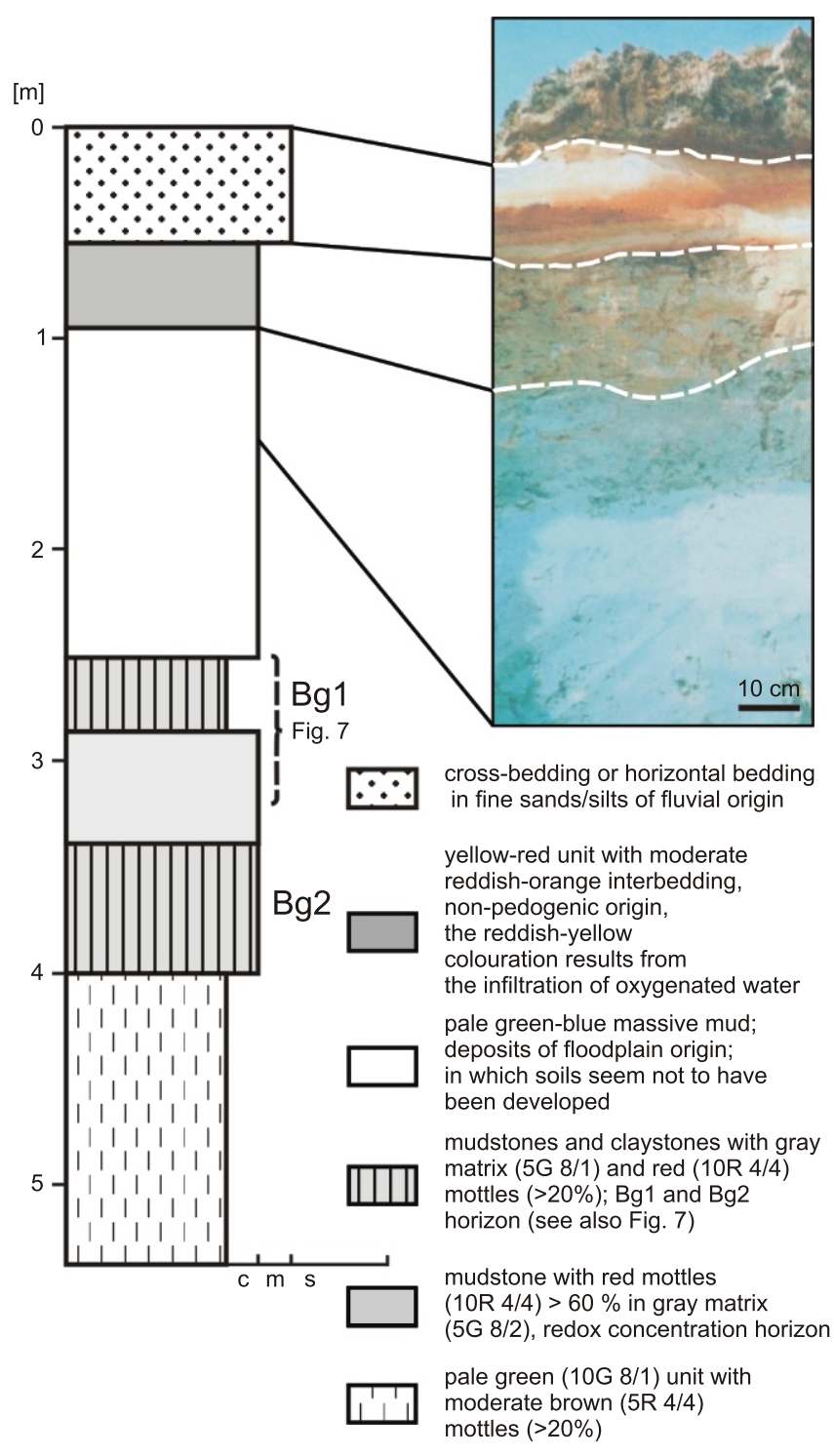

Fig. 6. Simplified lithological profile of palaeosols in the Witaszyce open pit with preserved redoximorphic features

Redox depletion and redox concentration; redox depletion is indicated by gray, yellow and green colours of the clay matrix (at the top of the palaeosols) and redox concentration at the bottom of the profile (see also Fig. 7); the yellowish-red clays at the top of the profile have infiltrated features and a non-pedogenic origin; at the top glacigenic deposits overlie the silts; other explanations as in Figure 5

in the variegated sediments there are mottles of irregular shape, causing colour change (reddening). In some places there are so many of them that the sediment is almost entirely red, of brick-like colour.

\section{CRYSTALS (CRYSTALLARIA)}

The deposits commonly contain gypsum which occurs as single crystals, groups of crystals, spherical aggregates (spherulites) or tabular aggregates (crystal tubes), void infills, and cracks. In the soil science nomenclature such clusters of crystals are called mineral cancer (or crystallaria), most of which crystallize in free spaces in soils as the fillings of post-root voids or cracks.

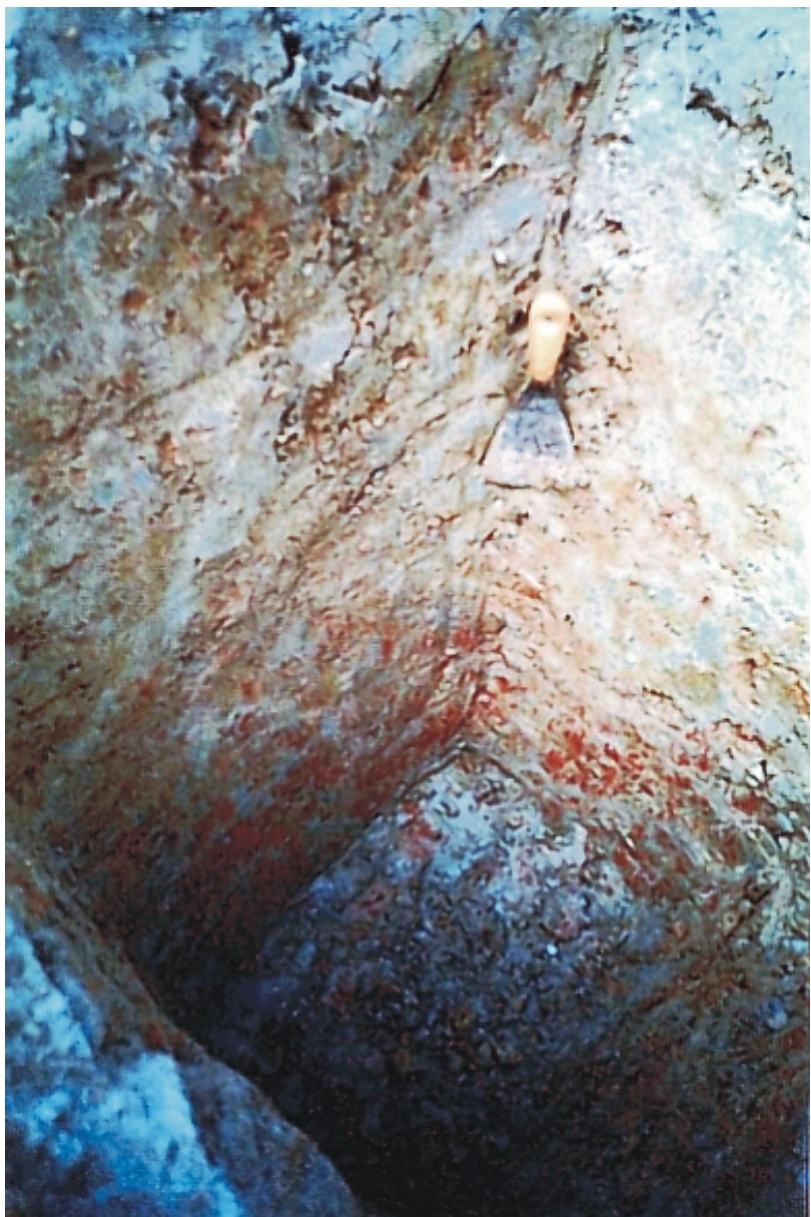

Fig. 7. Colour changes in claystones from the Witaszyce open pit with the advancing reddening (redox concentration) downwards profile (about $3 \mathrm{~m}$ below the surface, Fig. 6)

At the top of this part of the profile the gleying process is manifested by bluish-gray colour with redoximorphic pedostrucures; the reddening part indicates redox concentration; the spatula is $25 \mathrm{~cm}$ long (photo by M. Sroka)

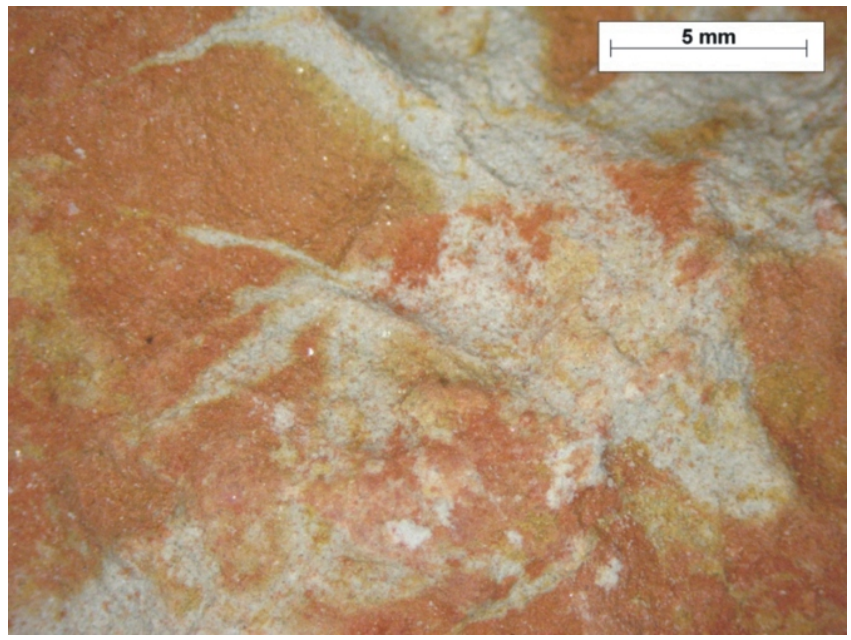

Fig. 8. Redoximorphic pedostructures in the horizon of the redox concentration manifested by the mottles formed (red hematite and yellowish-brown goethite) from the lower part of the profile (Bg horizon)

The sediments with iron oxides are red while those without iron oxides are green, referred redox depletion - the reddening is caused by the presence of hematite; the Brzostów open pit 


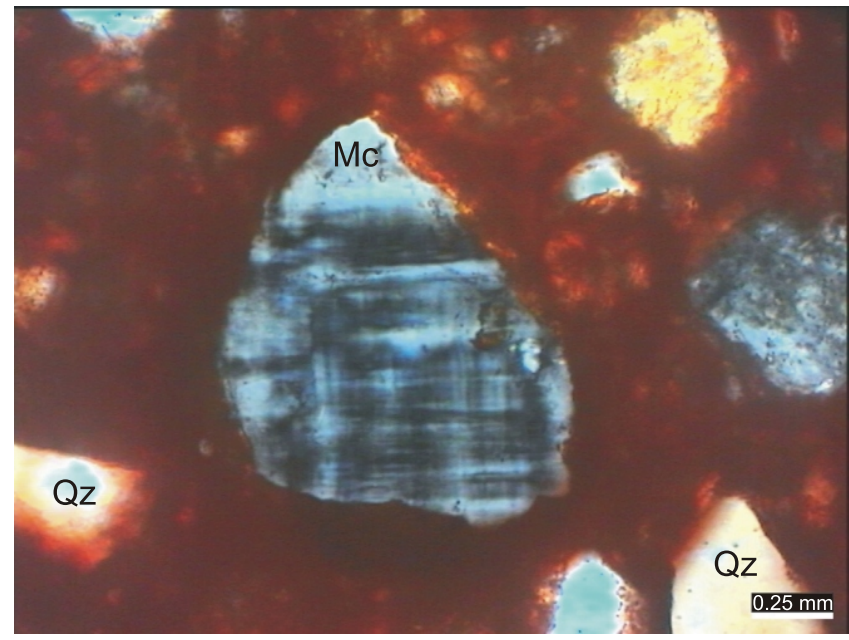

Fig. 9. Transmitted-light photomicrograph of iron oxides cementing skeletal grains

Qz - quartz; Mc - K-feldspar (microcline) in the reddening level of palaeosols from the Brzostów open pit (Fig. 8 enlargement); skeletal grains are resistant to chemical weathering

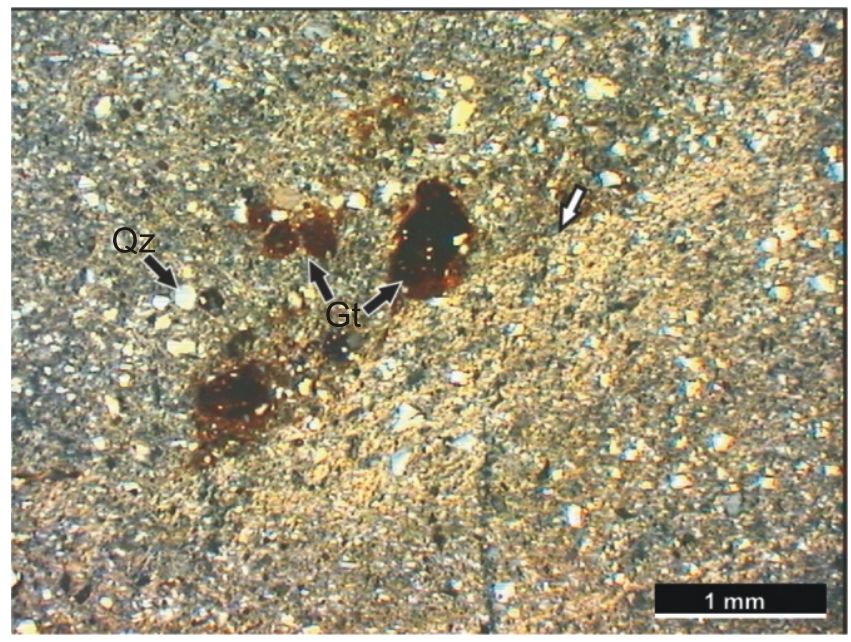

Fig. 11. Photomicrograph of gleyed sediments from the middle part of the Dymaczewo exposure (Bky horizon)

The content of quartz grains rises to about $20 \%$, the content of globules is less than 10\%; explanations as in Figures 9 and 10

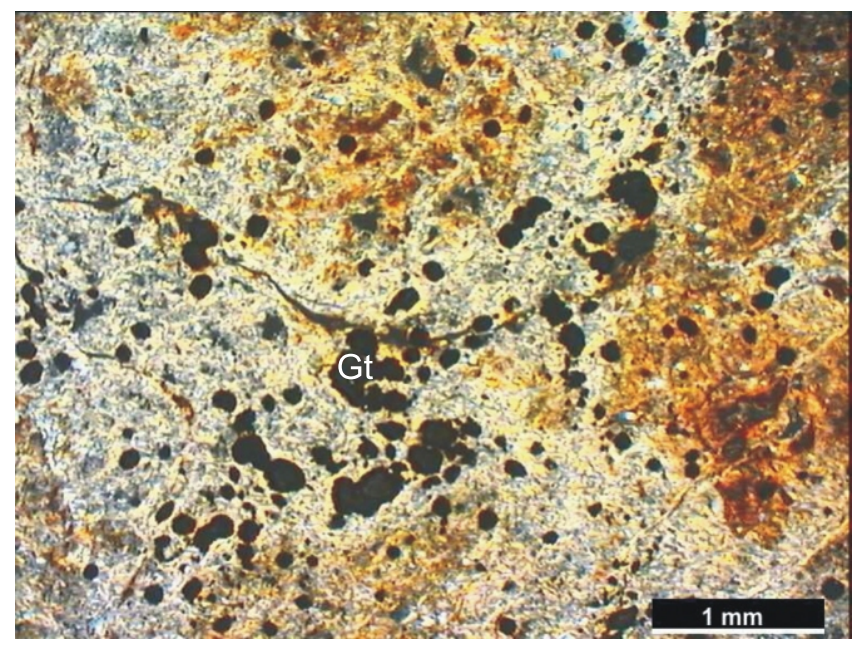

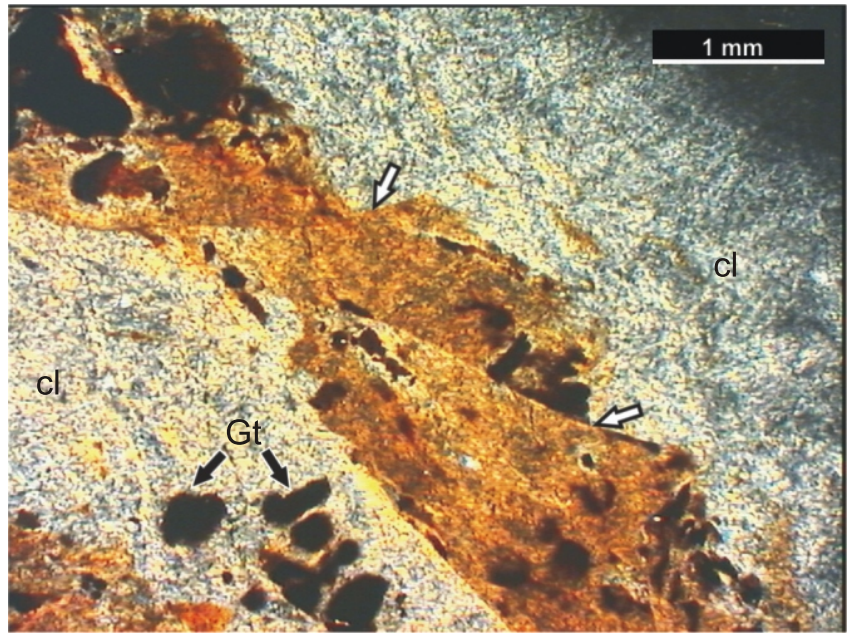

Fig. 10. Transmitted-light photomicrograph of the upper part (2Bss horizons, Fig. 5A) of the modern soil profile, consists mainly of clay matrix, mottled due to the presence of iron oxides, trace amounts of quartz grains

$\mathrm{cl}$ - clay; Gt - goethite; white arrows - slickensides emphasised by iron oxides; the Dymaczewo exposure (plane polarized light)

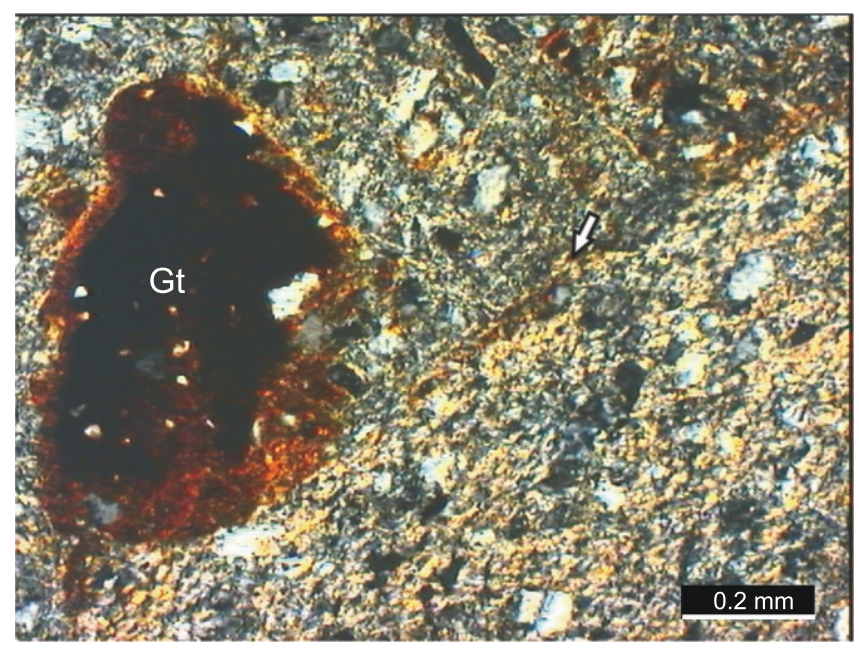

Fig. 12. The iron globule consists of goethite cementing quartz grains and clay minerals

Quartz grains are very well-sorted, and relatively poorly rounded; enlargement of the Figure 11 (transmitted-light, plane polarized light); explanations as in Figure 10

Fig. 13. Transmitted-light photomicrograph of mottles and fine to coarse globules consisting of iron-manganese oxides, up to $50 \%$ of matrix is built of clays

The Dymaczewo open pit (crossed polars), corresponds to 2Bss horizon in Figure $5 \mathrm{~A}$; explanations as in Figure 10 


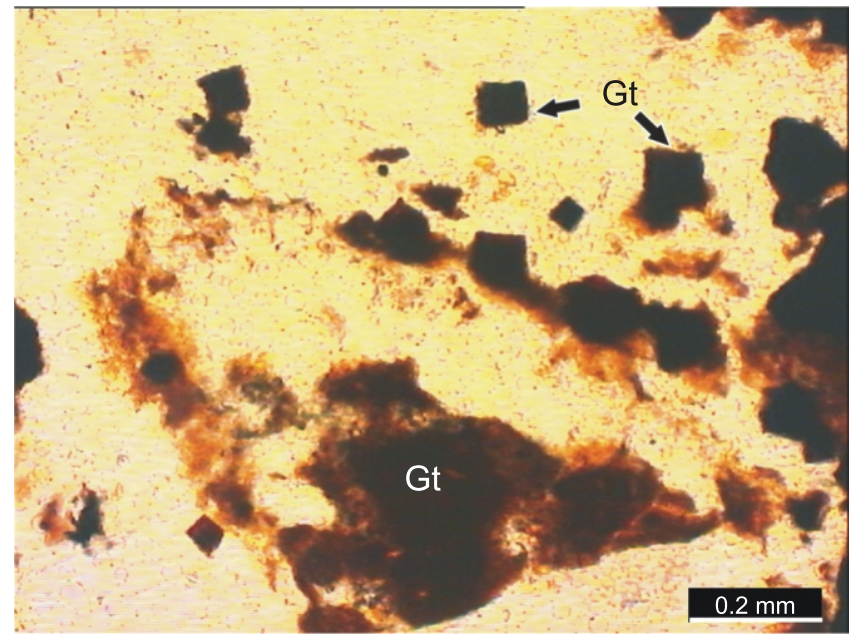

Fig. 14. Photomicrograph of goethite microcrystals, probably pseudomorph after fine euhedral pyrite crystals (Fig. 13 enlargement, plane polarized light)

Explanations as in Figure 10

\section{CARBONATE CONCRETIONS (CALCRETES)}

In general, there are two types of carbonate concretions which differ in form and size as well as their position in relation to the surface and mineral and chemical composition:

- calcitic and marly concretions of a few to several centimetre across; marly concretions, locally developed as lenses or horizons, are built of calcite with admixtures of clay minerals; they are found in green clays;

- calcite with admixtures of manganese and iron (Fig. 15) and calcite-dolomite, gray-green with yellow and red spots, locally speckled with globular clusters of iron-manganese oxides, ranging in size from several centimetres to one metre across, strongly fractured and with cracks filled with calcite (known as septaria concretions or honeycomb-type); these lithologies are found in the red and brown clays, locally as concretion horizons.

Microchemical analysis (Duczmal-Czernikiewicz, 2010) showed that calcite with some magnesium content is the main component of spherulites of carbonate nodules. Calcium oxide content in the carbonates reaches $15 \mathrm{wt} . \%$, while the content of $\mathrm{Sr}$ and $\mathrm{Ba}$ is much higher in carbonates than in the clayey beds (Table 2, sample D2). Concretions are often composed of micrite carbonates which cement grains of quartz or feldspar. Spherulites commonly develop around the detrital grains of quartz or feldspar.

\section{CLAY MINERALOGY}

The mineral composition of the lithologies investigated shows high contents of detrital components. The dominant minerals of the mudstones and siltstones are quartz and muscovite, while feldspars occur sporadically. They are accompanied by varying amounts of mixed-layer illite-smectite, illite and kaolinite. Among the iron minerals goethite and hematite were found. Fine clay fractions have a monotonous mineral composition. The following were recorded: kaolinite, illite, smectite, illite-smectite, chlorite and, rarely, halloysite. Minerals commonly occurring as impurities include detrital quartz and, lo-

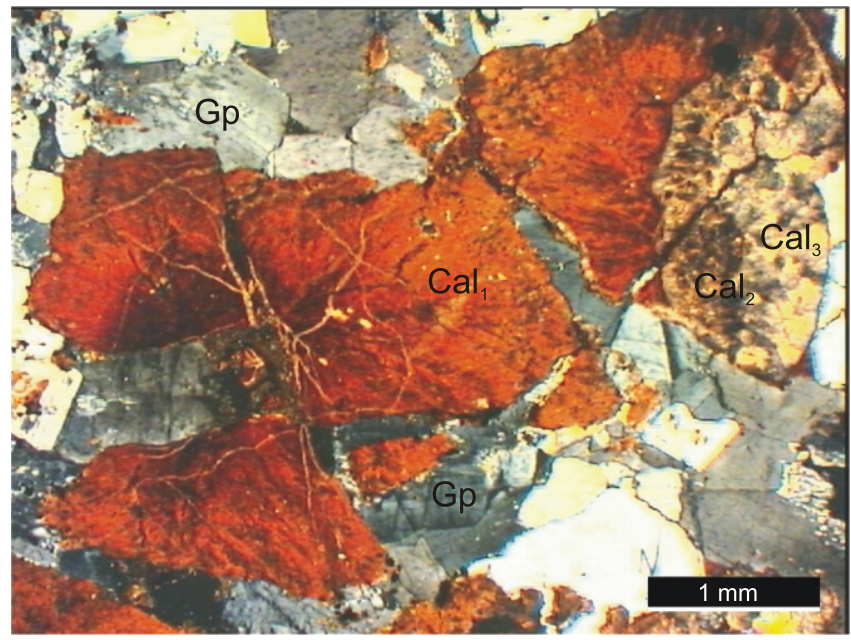

Fig. 15. Transmitted-light photomicrograph of calcite spherulites, crushed and rimmed by generations of secondary calcite $\mathrm{Cal}_{1}$ and $\mathrm{Cal}_{2}$

The red colour of the calcite spherulite results from the admixture of fine crystalline iron oxides; the Dymaczewo open pit; $\mathrm{Cal}_{1}$ - first generation of calcite, $\mathrm{Cal}_{2}$ - second generation of calcite, $\mathrm{Cal}_{3}-$ third generation of calcite, Gp - gypsum

cally, feldspars. The smectite phases of illite-smectite and smectite are present in most lithologies studied, and most samples contain illite-smectite mixed-layer minerals. A comparison of the diffraction patterns of untreated samples analysed using the Greene-Kelly (1953) test shows beidellite, that had previously been found in deposits of the Poznan succession by Wiewióra and Wyrwicki (1974, 1976). It has been estimated (Moore and Reynolds, 1989) that the share of swelling layers in the minerals of mixed structure is between 50 and $90 \%$. Kaolinite is present in varying proportions in each sample. Halloysite is rare, both in the $<2 \mu \mathrm{m}$ and $<0.2 \mu \mathrm{m}$ fraction. Illite is common while chlorite occurs only occasionally in the fractions $\phi<2 \mu \mathrm{m}$ and $\phi<0.2 \mu \mathrm{m}$ fractions. An example of a diffraction pattern is shown in Figure 16.

\section{INTERPRETATION OF SOIL HORIZONS}

In the exposures studied the following soil horizons were recognised:

$\mathrm{O}$ - the humus level, almost $70 \mathrm{~cm}$ thick (N2 in the Munsell colour system), contemporary litter, brittle and with addition of coarse quartz grains;

$\mathrm{Bw}$ - in the upper part these deposits, up to $100 \mathrm{~cm}$ in depth, are usually of yellowish-reddish (7.5YR in the Munsell system) or rusty (2.5YR) hue, with many fine iron nodules and slickensides;

$\mathrm{BK}$ - greenish-bluish deposits below Bw (10BG and $5 B G$ ) with a level of calcite concretions that are elongate or ellipsoidal, up to $70 \mathrm{~cm}$ of diameter, with predominant mud-clay or mud fraction (20-25\%);

Bky - calcic soils or carbonate concretion level (concretions up to $1.5 \mathrm{~m}$ in diameter), brecciated, with gypsum pedofeatures as elongate crystals or rosettes;

Bss - several horizons with slickensides at the top and bottom of the Dymaczewo profile; these are usually red or spotted red-green deposits. In terms of grain-size distribution the deposits studied are characterized by a pre- 
A Data from 20 Bll-11-o (multiple diagram)

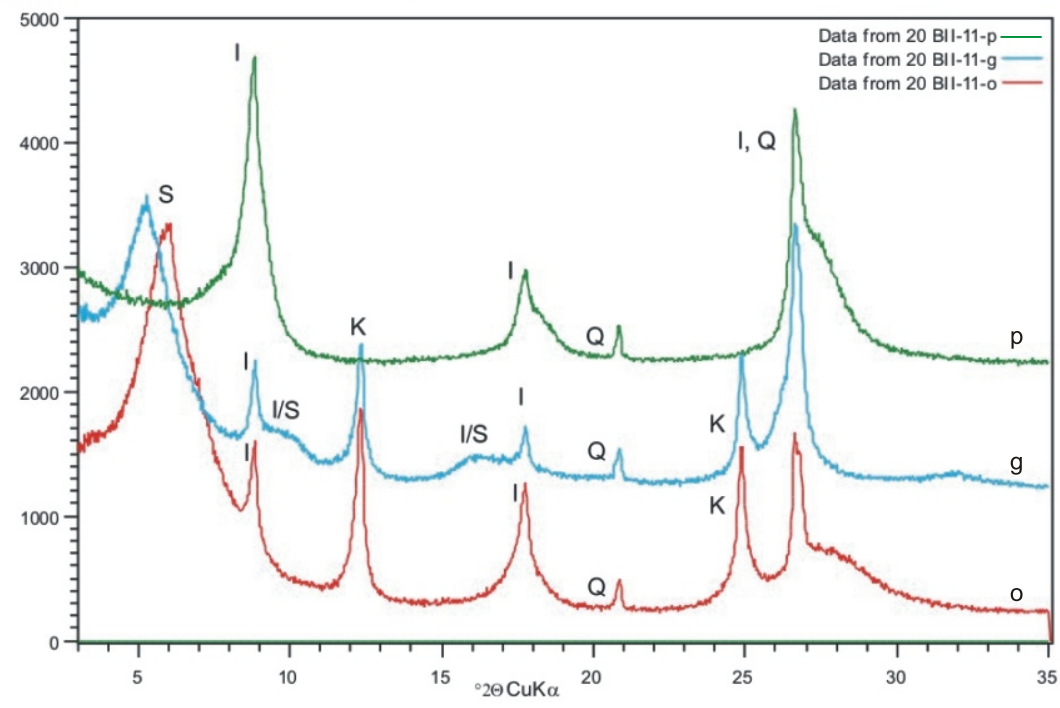

B

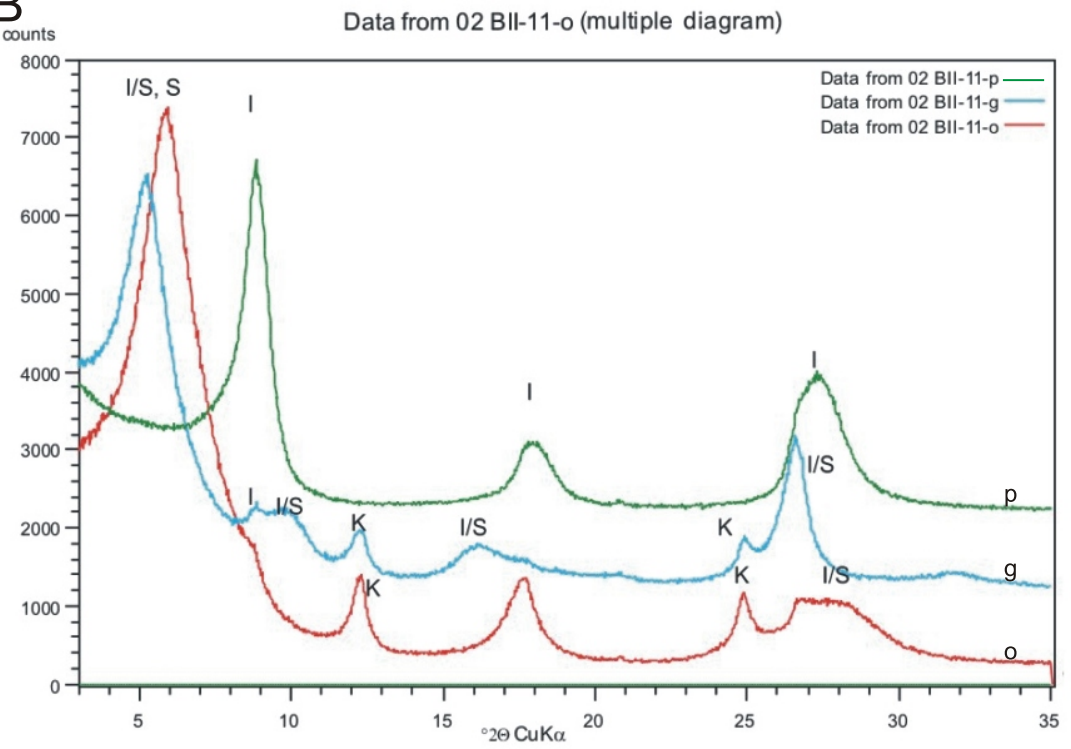

C

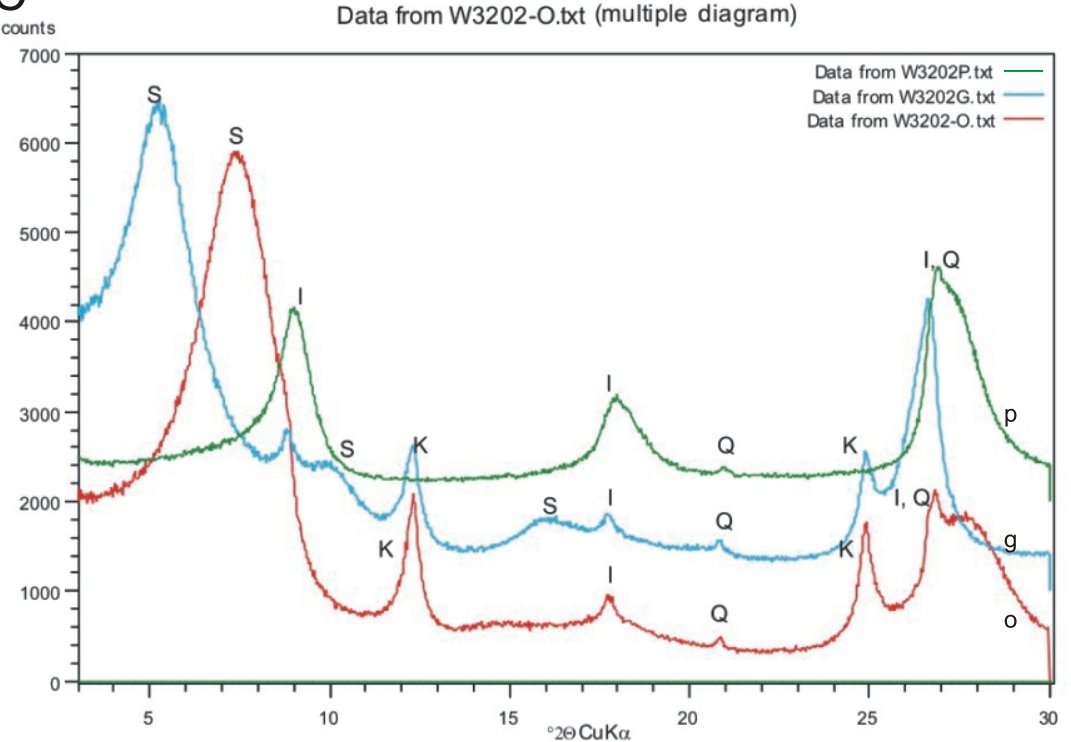

Fig. 16. XRD patterns for the clay fraction at the top of the exposures

A - B II - Brzostów, level II $(\phi<2 \mu \mathrm{m})$, fraction level $(\phi<2 \mu \mathrm{m})$, Bg horizon; B - B II - Brzostów, level II $(\phi<2 \mu \mathrm{m})$, fraction $(\phi<0.2 \mu \mathrm{m})$, Bg horizon; C - W - Witaszyce, level III, Bg horizon, fraction level $(\phi<0.2 \mu \mathrm{m}) ; \mathrm{I}$ - illite, I/S illite-smectite, $\mathrm{K}$ - kaolinite, $\mathrm{S}$ smectite in different ratios compose the soils and palaeosols; besides clay minerals, small admixtures of quartz were observed; Q - quartz; $\mathrm{p}$ - heated, g glycol - intercalated, o - oriented 
dominance of the clay fraction $(60-75 \%)$, mud-clay or mud (20-25\%), although in places the sand and silt fractions increase ( $10 \%$ on average, maximum up to $20 \%$ );

$\mathrm{Bg}-(2.5 \mathrm{R}$ in the Munsell system) with redoximorphic features around root traces, in Brzostów with clay illuviation (rare) and amorphic iron coatings with many slickensides (Fig. 5A);

BC - transitional level between B and C horizons, (grey-blue) horizon slightly influenced by pedogenesis, with structural and textural characteristics of the parent rock; muddy clay, slightly horizontally stratified, in places with coarse quartz detritus.

Granular texture, which occurs at least three times in the Dymaczewo exposure (Fig. 4), may indicate the uppermost horizons of soils (topsoil). Slickensides are diagnostic soil pedofeatures in horizons Bss. In the sedimentary profiles studied in Dymaczewo several (at least 3) Bss horizons were observed (Fig. 5A), while in Brzostów one Bss level occurs.

In the Witaszyce exposure levels of reddening occur indicating palaeosols, although there is also modern weathering observed, with no pedofeatures (Fig. 6). The reddening starts at a depth of $3.5 \mathrm{~m}$, and there is a level of gleying where redoximorphic pedostructures were recognized.

Several levels (soil horizons) containing iron globules were recognized in each of the exposures examined. Iron nodules and concretions indicate Bo or Bg soil horizons, which occur in a lower part of the Dymaczewo profile. Under the iron oxide horizon a manganese-enriched level was observed. In the Brzostów profile manganese globules in a green part of the profile were visible, while iron oxides are typical of redoximorphic structures, specific for a lower part of the profile (Figs. 8 and 9) at a depth of $2.5 \mathrm{~m}$ below the modern surface.

\section{CLIMATIC IMPLICATIONS}

The morphological, mineralogical and chemical features, particularly the presence of nodules and gypsum levels, clearly show an increase in climate dryness as a result of reduced water availability. At the same time, gypsum morphology, especially the presence of traces of "desert roses", suggests that the lower palaeosol horizons, where the development of modern soils is not observed, formed in older deposits. This might have taken place before the Pliocene, as the Poznań Formation has developed since the Mid-Miocene to Pliocene, and the rocks found in this area are treated as Mio-Pliocene. In the research area there are no stratigraphic reference points. Moreover, organic elements (such as pollen), used for determining age sequences, are usually dissolved in pedogenic processes by fulvic acids.

There exist both Miocene and Pliocene palaeosols. Mid-Miocene palaeosols might be associated with the Badenian salinity crisis (Peryt, 2006; Krijgsman and Meijer, 2008; de Leeuw et al., 2010). Palaeosols from around the Miocene-Pliocene boundary are known from many places, including present-day Spain, France, Italy, Cyprus and Turkey (Cappadocia; e.g., Fortuin and Krijgsman, 2003; Lepetit et al., 2006; Domingo et al., 2009). In Paratethys area evidence of hydrological changes and crystallisation of evaporites has been observed. This was due to salinity changes as a result of the Messinian salinity crisis, during which forty alternations of flooding and drying out took place. As a result of flooding and evaporation processes, changes in the characteristics of marine sediments on land are observed over an area of more than one million sq. km (including pronounced changes in the chemical, mineral and isotopic composition, as well as in change of biocenosis composition). Such changes undoubtedly influenced sedimentation on Paratethys itself and in more distant areas.

Horizons containing gypsum and carbonate concretions might therefore reflect terrestrial sedimentation (originally developed on fluvial deposits) resulting from repeated drying of water bodies between 5.96-5.92 million years ago. In periodically flooded, alternating wet and dry periods, Vertisols might have developed with horizons of gypsum and carbonate nodules, which might correspond to the petrocalcic horizons of Cappadocia formed during the Messinian crisis peak dated to the Early Pliocene (Lepetit et al., 2006; de Leeuw et al., 2010).

\section{DISCUSSION}

The original sediments might have been deposited in a slow sedimentation regime. However, the observed upwards-fining cyclicity (Dyjor et al., 1968; Wyrwicki, 1975; Wichrowski, 1981; Górniak et al., 2001), is ascribed to deposition from very low energy rivers (Piwocki et al., 2004). The Poznań Formation clays were primarily formed in river floodplains (Różycki, 1972; Piwocki et al., 2004). The existence of fluvial transport and a well-developed river network in the Late Miocene and Pliocene has been documented by Badura and Przybylski (2004).

Periodic floods were interrupted by times when the sediments dried out. Sufficiently long dry periods might have favoured the development of soil (Piwocki et al., 2004). Soil formation processes led to the formation of typical soil morphologies, such as horizonation, iron-manganese globules, or carbonate concretions.

Horizonation is a basic structural feature of soils and palaeosols (Retallack, 1997). Changes of the green colour into red, in the form of brightly coloured stains derived from iron oxides, reflect the oxidation zone in the conditions of good oxygenation of the waters. The reddening appears in the green clays with varying intensity. Yellowish-rusty stains are present in studied each exposure at the top horizon (see photos in Figs. 4A, 5A and 6), while these intensively red, ruby (Witaszyce; Figs. 6 and 7) or brick colours (Brzostów; Figs. 8 and 9) are always present in the profiles below the top, and are separated from the rusty-yellow zone by blue-green clays.

Alternating grey, green and red as well as rusty-coloured deposits, green (blue) and red with intensive hues and chromas, may be the result of changes in $\mathrm{pH}$ and Eh of the environment and probably represent periodic drying (Chesworth, 2008). This is due to changes in water conditions in the top soil layers exposed by erosion, namely waterlogged into well-drained. Seasonally changing dry and wet hydrological conditions caused the fragmentation into sharp-edged peds. Indirectly this stems from the original grain size of the parent sediment.

The green or green-blue levels were formed by gleying processes. Gleying is the process whereby the iron in soils and sediments is bacterially reduced under anaerobic conditions and concentrated in a restricted horizon within the soil profile; "...gleying usually occurs where there is a high water table or where an iron pan forms low down in the soil profile and prevents run-off, with the result that the upper horizons remain wet..." (Chesworth, 2008). Above the green levels yellow-brown levels usually occur, coloured by the presence of rusty goethite, whereas below green-blue levels, red horizons occur, coloured by the presence of hematite (red and dark red). This might indicate that rusty horizons were the result of re-oxidation (Kraus and Hasiotis, 2006). The reddening in the lower part of succes- 
sion might be the result of migration of iron compounds around roots and water availability. The root remnants were probably bacterially decomposed after the sediments had been buried (Retallack, 1991; Blodgett et al. 1993; Sheldon, 2005; Makeev, 2012).

The green colour is the result of the presence of the $\mathrm{Fe}^{2+}$ compounds. Originally, they might have been present as very finely dispersed pyrite. Pseudomorphs of iron oxides and hydroxides after idiomorphic pyrite crystals are frequently found in the Bss horizons. The chemical conditions, determined by water availability, neutral or high $\mathrm{pH}$, and relatively low contents of oxygen, might have been sufficient for the formation of siderite concretions in the waterlogged environment (Chesworth, 2008).

Slickensides are meso- and microscale structures. They are the result of the reduction in clay volume, in which smectites are the dominant component during dry periods, and renewed increase in clay volume during wet periods. Slickenside structures are typical of the Vertisol, which means the soil saturated with water and with low chroma. Despite the conditions of hypoxia, the sediments may also have a red hue typical of oxygenated environment.

Zones enriched in clay minerals by over $15 \%$ and a predominance of silicates in the 2:1 structure (smectite, illite) are gley horizons. These are the horizons where slickensides, specific to Vertisols, are mostly observed. Vertisols are typical of waterlogged conditions with limited access of oxygen. A characteristic feature of this type of soil is a brown hue, but they can also be red (Kraus, 1997, 1999). Slickensides are described as a typical feature of soil processes taking place during periodic drying of the surface sediments (Retallack, 1997) and formed throughout the entire geological history of the sediments, including in modern times.

Massive-aggregate and small-aggregate, lumpy and grainy structures are products of the weathering of soil bedrock. A higher content of sand and silt fractions indicates a higher susceptibility to the formation of small aggregates. Thus, this contemporary feature depends on the initial structure of the soil bedrock.

The texture, structure and the size of the aggregates are morphological features of both soils and palaeosols. The occurrence of small-aggregate clay at the top and thick, massive clay at the bottom of the outcrops might indicate the secondary character of aggregation. There are places exposed for several decades, though, which underwent intense chemical weathering and contemporary soil-forming processes. However, they are massive and very hard, similar to lithified siltstones. Small fragments are therefore typical of some soil horizons, as the intensity of weathering grows. The most important outcome of the increased weathering is an increase in the sandy fraction, which reduces firmness and forms small aggregates. Simple regular-shaped (angular blocky and subangular blocky) and lumpy (granular) structures, as well as grainy small-aggregate (crumb) ones, are products of the weathering of the primary soil bedrock. Thus, this secondary feature depends on the initial grain composition of the soil bedrock.

Iron-manganese globules, so called "pepper" (Dyjor, 1992; Piwocki et al., 2004), are formed in oxidizing conditions. They are formed by oxidation of $\mathrm{Fe}^{2+}$ to $\mathrm{Fe}^{3+}$ at $\mathrm{pH} 7-8$. Manganese concretions require a lower $\mathrm{pH}$ and lower salinity of the environment. They were only recorded in one of the exposure discussed.

The red deposits might have been formed in oxygenated and well-drained conditions which periodically dried out. Such conditions on the Polish Lowland have already been noted by Różycki (1972) and Dyjor et al. (1968). In this environment,
$\mathrm{Ca}^{2+}$ ions were leached out and transported into the lower layers, allowing for the formation of carbonate concretions and carbonate levels, layers and lenses. The development of nodules and levels of carbonate concretions (calcretes) may be pedogenic or non-pedogenic (Retallack, 1997). Pedogenic nodules and diagenetic concretions may have similar morphological characteristics. In both cases, nodule levels may be called calcretes (Retallack, 1989, 1991; Wright, 1992). The depth of the pedogenic nodules in the soil profile allows definition of the size of the mean annual rainfall as well as the temperature and climate during their formation (Retallack, 2004; Sheldon and Tabor, 2009). For many years, concretions in the Poznań clays were described as non-pedogenic but there exist both pedogenic and non-pedogenic.

The effects of carbonate dissolution, shrinkage and recrystallisation of carbonates in cracks as septarian structures and carbonate breccias are observed. These processes are superimposed successively with crystallisation of sulphates due to changes in the chemistry of the solution (alkaline $\mathrm{pH}$ and positive Eh) and the associated destruction of the original organic matter common in waterlogged soils.

Gypsisol is a distinct gypsum-enriched level, which developed most fully in Dymaczewo. This horizon contains single or rosette crystals accompanying carbonate concretions. Rosettes and "desert roses" forms of gypsum indicate extremely dry and arid conditions. They were also found in earlier studied exposures (Wiewióra and Wyrwicki, 1974). As these deposits very easily dissolve and precipitate they can be highly migratory.

Clay fractions show a development typical of terrestrial sediments, and mostly originated from the weathering of previous, fluvial sedimentary rocks. The dominant illite-smectite might have developed as a result of illitization of smectite in varying hydrological conditions. According to Wilson (1999) and Kraus (1999), this process can occur in seasonal wet-dry climates. Such conditions are typical for Vertisols dominated by 2:1 type layered minerals. The content of smectite in the mixed-layered minerals (from 30 to 80 smectite layers, up to $80 \%$ ) also are typical of Vertisols. The mineral composition of the clay fraction is also dependent on the physicochemical conditions. The presence of the mixture of kaolinite, illite and smectite in the sediment requires weakly alkaline and neutral conditions, as it stems from dependence of the mineral composition on $\mathrm{pH}$.

The mineral composition of the clay fraction is the result of weathering of fluvial material. The abundance of kaolinite, at locally up to $20 \%$, may be the result of fluvial accumulation of the intensely weathering Sudetes mountain ranges (see e.g., Biernacka, 2004; Piwocki et al., 2004).

Variegated patches and globules correspond to periods of drying out and drainage of water through the soil profile - all these structures are typical of alternating dry and wet periods.

Differences in morphology and mineral composition suggest that either sedimentary rocks found in different places belong to different parts of soil profiles or they were formed in different hydrological conditions. They formed stacked profiles up to $5 \mathrm{~m}$ deep; their pedological features suggest that they are probably truncated, because of some parts of the profiles are missing. There are BC horizons with weakly developed pedostructures. The profile at Dymaczewo contains modern soil at the top superimposed on the older soils, with no clear stratigraphic position. They might have been developing from the Pleistocene to the Holocene, as the morphology of this area was shaped during this interval (Kozarski, 1991). In the Brzostów and Witaszyce profiles gleyed palaeosols were recognized, which might be even older (Pliocene) indicating a wetting episode, as concluded from the amount of root traces, from a few millimetres to several centimetres in diameter. 
Many authors have reported changes in the Pliocene epoch from wetter to dryer conditions (Griffin, 2002; Piwocki, 2002; Utescher et al., 2011). On the other hand, the end of the Miocene (Messinian) is characterized by sedimentation in dry and arid conditions (Griffin, 2002) which might have formed sulphate levels (gypsisols). At the present-day there are very few geological signals which would help differentiate Miocene from Pliocene sedimentary rocks in many areas of Africa, Asia and Europe (Utescher et al., 2011). On the Polish Lowland, sedimentary deposits from the mid-Late Miocene $(8.5 \mathrm{Ma})$ to the Late Pliocene (1.8 Ma) have been interpreted as fresh lake and marsh beds (according to Popov et al., 2004). The position of both root traces, and the sulphate horizons in the deposits studied, might be an additional "fingerprint" for determining the type of sedimentation, weathering during pedogenesis and climate changes in this part of Europe.

The interpretation should also take into account the microstructural characteristics, such as the size of the components, slickensides and plant root traces. In the deposits examined the traces of an increasingly dry climate are manifested in the form of a gypsum horizon and traces of crystals similar to desert roses (Duczmal-Czernikiewicz, 2011). They are observed only in some exposures. During chemical weathering the components necessary for the creation of gypsum were released: sulphur ions from the weathering of pyrite and calcium ions from the dissolution of concretions, as indicated by the position of gypsum around the carbonate concretions.

Modern soil processes are overlapped by younger soil processes that can disrupt and alter the original character of the sediments. They occur in the top layers of the operating pits causing horizonation, fragmentation of the sediment due to penetration by plant roots and chemical changes in the sediment due to migration of mobile compounds.

All the above structural and mineralogical characteristics might correspond to the descriptions of Vertisol soils and palaeosols which developed on waterlogged fluvial sediments which periodically underwent drying (Driese et al., 2003). The evidence is marked by the red and green horizons, gypsum levels, the levels of carbonate concretions, the mineral composition of the clay fractions, slickensides, iron-manganese globules and the chemical composition of the sediments.

\section{CONCLUSIONS}

The mineral and chemical composition of the deposits studied is the result of weathering processes (including soil processes) affecting clayey-sandy sediments, which were originally a fluvial sedimentary facies. Presently, the Upper Poznań Formation is poor in pollen, and so weakly constrained biostratigraphicaly. Originally, they might have contained many organic remains, but as a result of changes in physical and chemical conditions due to soil processes, very few or none of these have remained. For this reason, their stratigraphic position should be determined by structural and mineralogical-geochemical methods.

The dominant fine fractions - silt-clayey and clayey - as well as a certain cyclicality of sedimentation may denote deposits carried by a very low energy river (the environment corresponding to floodplains). Increases in the sand and silt fraction reflects greater current speeds. Fluvial sedimentation, mainly as floodplain deposits, coincided with soil processes, which might have altered the quantitative relationship between the clay and sandy fractions due to clay particles being moved along the vertical profile and the relative increase in quartz in relation to other components of the sediment.

The stacked soils indicate changes in climatic and environmental conditions (aridity, availability of water), which are manifested by pedofeatures characteristic of wetting and drying cycles (slickensides), drying (calcite and gypsum horizons), a wet oxidized environment (iron-manganese concretions and nodules) and at least three horizons of root traces. These features might reflect climate seasonality during their formation in central Europe.

Acknowledgments. This study was supported by a grant of the Polish Ministry of Science and Higher Education (No. 3P04D 006 24). The author is grateful to the reviewers: R. Gaupp, A. O. Makeev, the anonymous reviewer and T. M. Peryt for the revision and valuable comments that significantly improved the manuscript. Special thanks to J. Zalasiewicz for language corrections.

\section{REFERENCES}

Alonzo-Zarza A.M. (2003) Palaeoenvironmental significance of palustrine carbonates and calcretes in the geological record. Earth-Science Reviews, 60: 261-298.

Alonzo-Zarza A.M., Arenas C. (2004) Cenozoic calcretes from the Teruel Braben, Spain: microstructure, stable isotope, geochemistry and environmental significance. Sedimentary Geology, 167: 91-108.

Alonzo-Zarza A.M., Wright V.P. (2010) Palustrine carbonates. Developments in Sedimentology, 61: 103-132.

Badura J., Przybylski B. (2004) Evolution of the late Neogene and Eopleistocene fluvial system in the Foreland of Sudetes Mountains, SW Poland. Annales Societatis Geologorum Poloniae, 74: 43-61.

Bamford M.K., Stanistreet I.G., Stollhofen H., Albert R.M. (2008) Late Pliocene grassland from Olduvai Gorge, Tanzania. Palaeogeography, Palaeoclimatology, Palaeoecology, 257: 280-293.

Biernacka J. (2004) Heavy mineral suites in Oligocene-Miocene sediments (Fore-Sudetic Monocline, SW Poland): provenance signals versus weathering alteration. Geologia Sudetica, 36: $1-20$.

Blodgett R.H., Crabaugh J.P., McBride E.F. (1993) The color of red beds - a geologic perspective. Soil Science Society of America, Special Publication, 31: 127-159.

Chesworth W., ed. (2008) Encyclopedia of Soil Science. Springer Dordrecht, Netherland.

Ciuk E. (1970) The lithostratigraphic schemes of Tertiary on the Polish Lowland (in Polish with English summary). Kwartalnik Geologiczny, 14 (4): 754-771.

De Leeuw A., Bukowski K., Krijgsman W., Kuiper K.F. (2010) Age of the Badenian salinity crisis; impact of Miocene climate variability on the circum-Mediterranean region. Geology, 38 (8): 715-718.

Domingo L., Grimes S.T., Domingo S.M., Albredi M.T. (2009) Paleoenvironmental conditions in the Spanish Miocene-Pliocene boundary: isotopic analyses of Hipparion dental enamel. Naturwissenschaften, 96: 503-511. 
Driese S.G., Jacobs J.R., Nordt L.C. (2003) Comparison of modern and ancient Vertisols developed on limestone in terms of their geochemistry and parent material. Sedimentary Geology, 157: 49-69.

Duczmal-Czernikiewicz A. (2010) Geochemistry and mineralogy of Poznań Formation (Polish Lowland). Wydawnictwa Naukowe UAM, Poznań.

Duczmal-Czernikiewicz A. (2011) Microfabric of the Poznań clays in microscopic investigation as the indication of the polygenetic origin of sediments (in Polish with English summary). Biuletyn Państwowego Instytutu Geologicznego, 444: 47-54.

Dyjor S. (1970) The Poznań series in West Poland (in Polish with English summary). Kwartalnik Geologiczny, 14 (1): 819-835.

Dyjor S. (1986) Evolution of sedimentation and palaeogeography of near-frontier areas of the Silesian part of the Parathetys and the Tertiary Polish-German Basin. Zeszyty Naukowe AGH, Geologia, 12: 7-23.

Dyjor S., Bogda A., Chodak T. (1968) Preliminary studies of the mineral compositions of the Poznań Clays (in Polish with English summary). Rocznik Polskiego Towarzystwa Geologicznego, 38 (4): 491-510.

Fortuin A.R., Krijgsman W. (2003) The Messinian of the Nijar Basin (SE Spain): sedimentation, depositional environments and paleogeographic evolution. Sedimentary Geology, 160: 213-242.

Gedl P., Worobiec E. (2005) Organic-walled dinoflagellate cysts from Miocene deposits of the Legnica-33/56 borehole (ForeSudetic Monocline) as indicators of marine ingression in southwestern Poland. Studia Geologica Polonica, 124: 395-410.

Górniak K., Szydłak T., Sikora W., Gaweł A., Bahranowski K., Ratajczak T. (2001) Minerały ilaste w różnobarwnych odmianach skał występujących nad pokładem węgla brunatnego w rejonie Konina. Górnictwo Odkrywkowe, 43 (2-3): 129-139.

Greene-Kelly R. (1953) The identification of montmorillonites. Journal of Soil Science, 4: 233-237.

Griffin D.L. (2002) Aridity and humidity: two aspects of the late Miocene climate of North Africa and the Mediterranean. Palaeogeography, Palaeoclimatology, Palaeoecology, 182: 65-91.

Hanneman D.L., Wideman C.J. (2006) Calcic pedocomplexes regional sequence boundary indicators in Tertiary deposits of the Great Plains and western United States. GSA Special Paper, 416: 1-15.

Kovács J., Varga G., Dezso J. (2008) Comparative study on the late Cenozoic red clay deposits from China and Central Europe (Hungary). Geological Quarterly, 52 (4): 369-382.

Kovda I., Mora C.I., Wilding L.P. (2008) Paleovertisols of the northwest Caucasus: (micro)morphological, physical, chemical, and isotopic constrains on early to late Pleistocene climate. Journal of Plant Nutrition and Soil Science, 171: 489-508.

Kozarski S. (1991) Paleogeografia Polski w Vistulianie. In: Geografia Polski - Środowisko przyrodnicze (ed. L. Starkel): 80-105. Wydawnictwo PWN, Warszawa.

Kraus M.J. (1997) Lower Eocene alluvial paleosols: pedogenic development, stratigraphic relationships and paleosol/landscape associations. Palaeogeography, Palaeoclimatology, Palaeoecology, 129: 387-406.

Kraus M.J. (1999) Paleosols in clastic sedimentary rocks: their geologic applications. Earth-Science Reviews, 47: 41-70.

Kraus M.J., Hasiotis S.T. (2006) Significance of different modes of rhizolith preservation to interpreting paleoenvironmental and paleohydrologic settings: examples from Paleogene paleosols, Bighorn Basin, Wyoming, U.S.A. Journal of Sedimentary Research, 76: 633-646.

Krijgsman W., Meijer P.T. (2008) Depositional environments of the Mediterranean "Lower Evaporites" of the Messinian salinity crisis: constraints from quantitative analyses. Marine Geology, 253: 73-81.

Lepetit P., Viereck-Goette L., Gurel A. (2006) Neogene paleosols in Cappadocia - archives of global changes in climate and vegetation in the Late Neogene. Geophysical Research Abstracts, 8, SRef-ID: 1607-7962/gra/EGU06-A-05637
Makeev A.O. (2012) Permian paleosols in relation to general issues of paleopedology. Eurasian Soil Science, 45 (1): 98-107.

Moore D.M., Reynolds R.C. Jr. (1989) X-Ray Diffraction and the Identification and Analysis of Clay Minerals. Oxford University Press.

Nettleton W.D., Brasher B.R., Behnham E.C., Ahrenst R.J. (1999) A classification system for buried paleosols. Quaternary International, 51/52: 175-183.

Nettleton W.D., Olson C.G., Wysocki D.A. (2000) Paleosol classification: problems and solutions. Catena, 41: 61-92.

Peryt T.M. (2006) The beginning, development and termination of the Middle Miocene Badenian salinity crisis in Central Paratethys. Sedimentary Geology, 188: 379-396.

Piwocki M. (2002) Evolution of concepts on the stratigraphy of the Poznań Formation deposits on the Polish Lowlands (in Polish). Przeglad Geologiczny, 50 (3): 255.

Piwocki M., Ziembińska-Tworzydło M. (1997) Neogene of the Polish Lowland - lithostratigraphy and pollen-spore zones. Geological Quarterly, 41 (1): 21-40.

Piwocki M., Badura J., Przybylski B. (2004) Neogen. In: Budowa geologiczna Polski. Tom I, Stratygrafia. Część 3a, kenozoik, paleogen, neogen (eds. T. Peryt and M. Piwocki): 71-118. Państwowy Instytut Geologiczny, Warszawa.

Popov S.V., Rögl F., Rozanov A.Y., Steininger F.F., Shcherba I., Kovac M., eds. (2004) Lithological-paleogeographic maps of Paratethys; 10 maps Late Eocene to Pliocene. Courier Forschungsinstitut Senckenberg, 250: 1-46.

Rasser M.W., Harzhauser M. (2008) Palaeogene and Neogene. In: The Geology of Central Europe. Volume 2, Mesozoic and Cenozoic (ed. T. McCann): 1031-1139. Published by the Geological Society, London.

Retallack G.J. (1989) Field recognition of paleosols. GSA Special Papers, 216: 1-20.

Retallack G.J. (1991) Soils of the Past: An Introduction to Paleopedology. Second Edition. Blackwell Science, Oxford.

Retallack G.J. (1992) The fossil record of soils. In: Paleosols, Their Recognition and Interpretation (ed. V.P. Wright). Blackwell Scientific Publication.

Retallack G.J. (1997) A Colour Guide to Paleosols. John Wiley and Sons, Chichester-Toronto.

Retallack G.J. (1998) Core concepts of paleopedology. Quaternary International, 51/52: 203-212.

Retallack G.J. (2004) Late Miocene climate and life on land in Oregon within a context of Neogene global change. Palaeogeography, Palaeoclimatology, Palaeoecology, 214: 97-123.

Różycki Z.R. (1972) Plejstocen Polski Środkowej na tle przeszłości w górnym trzeciorzędzie. Państwowe Wydawnictwa Naukowe, Warszawa.

Sheldon N.D. (2005) Do red beds indicate paleoclimatic conditions? A Permian case study. Palaeogeography, Palaeoclimatology, Palaeoecology, 228: 305-319.

Sheldon N.D., Tabor N.J. (2009) Quantitative paleoenvironmental and paleoclimatic reconstruction using paleosols. Earth-Science Reviews, 95 (1-2): 1-52.

Soil Survey Staff (1990) Soil Taxonomy A Basic System of Soil Classification for Making and Interpreting Soil Surveys. Second Edition. United States Department of Agriculture Natural Resources Conservation Service, http://www.itc.nl/ rossiter/Docs/NRCS/tax

Szyszło D. (1967) Physical and chemical features of clay fraction of the Poznań clays on the basis of their lithology (in Polish with English summary). Biuletyn Geologiczny, 9: 51-127.

Utescher T., Boehme M., Mossbruger V. (2011) The Neogene of Eurasia: spatial gradients and temporal trends - the second synthesis of NECLIME. Palaeogeography, Palaeoclimatology, Palaeoecology, 304: 196-201.

Walkiewicz Z. (1984) The Tertiary in Wielkopolska (in Polish with English summary). Seria Geologia, 10. Wydawnictwa Naukowe UAM, Poznań. 
Wichrowski Z. (1981) Mineralogical studies of clays of the Poznań series (in Polish with English summary). Archiwum Mineralogiczne, 37 (2): 93-196.

Wiewióra A., Wyrwicki R. (1974) Clay minerals in the mottled clay horizon of the Poznań series (in Polish with English summary). Kwartalnik Geologiczny, 18 (3): 615-635.

Wiewióra A., Wyrwicki R. (1976) Beidellite from the sediments of the Poznań series (in Polish with English summary). Kwartalnik Geologiczny, 20 (2): 331-341.

Wilson M.J. (1999) The origin and formation of clay minerals in soils: past, present and future perspectives. Clay Minerals, 34: 7-25.
Wright V.P. (1992) Paleosol recognition: a guide to early diagenesis in terrestial settings. Developments in Sedimentology, 47. Elsevier Science Publishers B.V.

Wyrwicki R. (1975) Mineral composition and economic value of variegated Poznan clays (Pliocene) (in Polish with English summary). Kwartalnik Geologiczny, 19 (3): 633-648.

Wyrwicki R., Maliszewska A. (1977) Utwory wegglanowe w osadach ilastych serii poznańskiej (neogen). Biuletyn Instytutu Geoligicznego, 298: 269-314. 